Witold SOBCZAK

Polska Akademia Nauk, Poznań

\title{
Wolność myśli, sumienia i wyznania w prawie polskim. Próba analizy pojęć - określenia zakresu
}

\section{Pojęcie i treść wolności sumienia i wyznania}

W olność sumienia i wyznania kształtowała się stopniowo w toku długotrwałych procesów historycznych i filozoficznych. Ubocznym efektem tego stanu rzeczy stał się fakt, iż zarówno w tekstach normatywnych różnych państw, jak i w aktach prawa międzynarodowego zakres wolności dotyczącej kultu religijnego oraz związanych z tym przekonań występuje pod rozmaitymi nazwami m.in. jako: „wolność religii”, „wolność wierzeń”, „wolność kultu”, „wolność myśli i przekonań”, „wolność sumienia i religii”, „wolność wyznawania i głoszenia religijnych, areligijnych, a także antyreligijnych idei i doktryn"1.

Warto zauważyć, że wbrew pewnej tradycji obowiązująca Konstytucja RP posługuje się pojęciem „wolność sumienia i religii” odchodząc od przyjętego w art. 111 Konstytucji z 17 marca 1921 r. ${ }^{2}$ i ugruntowanego w literaturze pojęcia „wolność sumienia i wyznania”. Źródła nie informują o przyczynach, dla których wprowadzono do Konstytucji pojęcie „wolności sumienia i religii” zamiast „wolności sumienia i wyznania”. W literaturze przypuszcza się, iż jest to efektem przyjęcia przez Konstytucję katolickiej terminologii zaczerpniętej z deklaracji Soboru Watykańskiego II o wolności religijnej Dignitas splendor ${ }^{3}$. Odmiennego zdania

M. Piechowiak, Wolność religijna - aspekty filozoficznoprawne, „Toruński Rocznik Praw Człowieka i Pokoju” 1994-1995, z. 3, s. 7-21; K. Pyclik, Wolność sumienia i wyznania w Rzeczypospolitej Polskiej (założenia filozoficzno-prawne), w: Prawa $i$ wolności obywatelskie $w$ Konstytucji RP, red. B. Banaszak, A. Preisner, Warszawa 2002, s. 435-462; M. Safjan, Wolność religijna $w$ konstytucjach państw europejskich, w: Kultura i Prawo. Materiaty III Międzynarodowej konferencji na temat Religia $i$ wolność religijna Unii Europejskiej. Warszawa, 2-4 września 2002, red. J. Krukowski, O. Theisen, Lublin 2003, s. 43-73.

2 Dz. U. RP 1921, Nr 41 poz. 267.

3 Zob. M. Winiarczyk-Kossakowska, Wolność sumienia i religii, „Studia Prawnicze" 2001, z. 1 (147), s. 27 i n. 
jest ks. J. Krukowski, stojąc na stanowisku, iż termin „wolność religii” został zaczerpnięty z międzynarodowych umów o ochronie praw człowieka i podstawowych wolności afirmujących prawo naturalne ${ }^{4}$. Ks. J. Krukowski nie zauważa jednak, że angielski termin „religion” może być tłumaczony zarówno jako religia, jak i wyznanie, a więc odwołanie się do aktów prawa międzynarodowego nie wyjaśnia powodu odejścia od pojęcia „wolność sumienia i wyznania”. W literaturze dość często nad kwestią tą przechodzi się do porządku dziennego ${ }^{5}$ lub jakby nie zauważając problemu utożsamia się wolność sumienia i religii z wolnością wyznania. Tak czyni J. Garlicki stwierdzając: „wolność sumienia i religii tj. wyznania" i dalej pisząc o wolności sumienia i wyznania, nie wnikając $w$ kwestie terminologiczne ${ }^{6}$. U podstaw takiego podejścia leży chęć utożsamienia polskich rozwiązań konstytucyjnych z treścią Europejskiej Konwencji o Ochronie Praw Człowieka i Podstawowych wolności, której artykuł L. Garlicki przywołuje. Dodać należy, że Konstytucja RP z 23 kwietnia 1935 r. $^{7}$ nie odnosiła się do kwestii wolności sumienia i wyznania utrzymując $\mathrm{w}$ tym zakresie $\mathrm{w}$ mocy przepisy Konstytucji marcowej. Konstytucja PRL z 22 lipca 1952 r. w art. 70 posiłkowała się określeniem „wolność sumienia i wyznania”. Wspomniane kwestie terminologiczne pomija milczeniem komentarz do konstytucji J. Bocia9 W doktrynie tłumaczy się czasem odejście od określenia „wolność sumienia i wyznania" jako znak zerwania z przyjętym na gruncie Konstytucji z 1952 r. zaliczaniem wolności, sumienia i wyznania do praw, które mogą być koncesjonowane przez państwo. Tak interpretują wspomniane kwestie terminologiczne A. Mezglewski, H. Misztal, P. Stanisz ${ }^{10}$. Zauważyć jednak należy, że pojęcie „wolność sumienia i wyznania” pojawiło się wcześniej przed uchwaleniem Konstytucji z 1952 r., a więc tłumaczenie to nie do końca jest przekonywujące. Nie można wykluczyć także i tego, że twórcy Konstytucji z 1997 r. pozostawali pod przemożnym wpływem treści Amerykańskiej Konwencji Praw Człowieka z 22 listo-

${ }^{4}$ Zob. J. Krukowski, Polskie prawo wyznaniowe, Warszawa 2000, s. 77.

5 Np. w podręczniku Prawo konstytucyjne, red. Z. Witkowski, Toruń 2002.

6 J. Garlicki zob. tegoż, Polskie prawo konstytucyjne, wyd. 9, Warszawa 2005, s. 113.

Dz. U. RP 1935, Nr39, poz. 227.

8 Dz. U. 1952, Nr 33, poz. 232 tekst jednolity po zmianach Dz. U. 1976, Nr 7 , poz. 36 (w tekście jednolitym treści te znalazły się w art. 82).

9 Zob. J. Boć, Konstytucje Rzeczypospolitej Polskiej oraz Komentarz do konstytucji RP z 1997, Wrocław 1998, s. 102-104.

10 A. Mezglewski, H. Misztal, P. Stanisz, Prawo wyznaniowe, Warszawa 2006, s. 62. 
pada 1969 r., w której w art. 12 ust. 1 mowa o wolności sumienia i religii ${ }^{11}$. Pamiętać także należy, że o „,wolności myśli, sumienia i religii”, a nie o „wolności myśli sumienia i wyznania” mowa w Dokumencie Spotkania Kopenhaskiego Konferencji w Sprawie Ludzkiego Wymiaru KBWE z 29 czerwca 1990 r. ${ }^{12}$

Mimo stosowania różnej terminologii zakres pojęciowy wydaje się w istocie niezmienny. Pod różnymi terminami kryje się ta sama treść sprowadzająca się do gwarancji wyznawania rozmaitych religii, zakazu dyskryminacji religijnej, możliwości przynależności do różnych kościołów, związków wyznaniowych i zbiorowości religijnych ${ }^{13}$. To jednocze-

11 Tekst art. 6 i art. 12 Amerykańskiej Konwencji Praw Człowieka przynosi Wolność religii, Wybór materiałów. Dokumenty. Orzecznictwo, tłum i oprac. T. Jasudowicz, Toruń 2001, s. 137. W treści art. 12 zatytułowanego wolność sumienia i religii stwierdzono: „1. Każda osoba ma prawo do wolności sumienia i religii. Prawo to obejmuje wolność posiadania lub zmiany swej religii lub przekonań oraz wolność praktykowania lub upowszechniania swej religii lub przekonań, indywidualnie lub wespół z innymi, publicznie lub prywatnie. 2. Nikt nie będzie podlegał ograniczeniom, które mogłoby stanowić zamach na jego wolność posiadania lub zmiany swej religii lub przekonań. 3. Wolność manifestowania swej religii lub przekonań może podlegać jedynie takim ograniczeniom, które są przewidziane przez prawo i są konieczne dla ochrony bezpieczeństwa publicznego, porządku, zdrowia lub moralności albo praw i wolności innych osób. 4. Rodzice lub opiekunowie, w zależności od przypadku, mają prawo do zapewnienia swym dzieciom lub podopiecznym wychowania religijnego i moralnego, które jest zgodne z ich własnymi przekonaniami”.

12 Wolność religii, Wybór materiałów. Dokumenty. Orzecznictwo, thum i oprac. T. Jasudowicz, Toruń 2001, s. 118. Por. także Prawo wyznaniowe, wprow. i oprac. W. Uruszczak, Kraków 1997, s. 42.

13 W literaturze zwraca się uwagę, iż termin „wolność sumienia i wyznania” jest w gruncie rzeczy ,zbitką pojęciową” bardziej zrozumiałą jako zwrot całościowy, swoisty idiom, niż wówczas gdy usiłuje się dokonywać analizy każdego ze składających się na to pojęcie słów. Szczególnie trudne i niezbyt owocne dla zrozumienia treści tego pojęcia jest analizowanie terminu „sumienie” z natury rzeczy bardzo wieloznacznego. Najczęściej pod pojęciem sumienie pojmuje się ,ś́wiadomość moralną zdolność wydawania ocen dotyczących wartości moralnej czynów człowieka w szczególności jego postępowania”. Zob. J. Dębowski, L. Gawor, S. Jedynak, K. Kosior, J. Zdybel, Mała encyklopedia filozofii, pojęcia, problemy, kierunki, szkoby, Bydgoszcz 1996, s. 448-449; por. także A. Andrzejuk, Prasumienie (synderesis) i sumienie (conscientia) w ujęciu św. Tomasza z Akwinu, „Roczniki Filozoficzne” 1997, t. XLV, nr 1, s. 67. Wychodząc z analizy etymologicznej zauważa się, że sumienie pierwotnie oznaczało „wątpienie”, ,poddawanie w wattpliwość”, ,podejrzewanie". Zob. A. Brückner, Słownik etymologiczny języka polskiego, Warszawa 1970, s. 526. W treści zwrotu „wolność sumienia i wyznania” termin „sumienie” zdaje się występować w węższym znaczeniu, jako zdolność do wydawania ocen, co do warto- 
śnie wolność posiadania różnych przekonań i różnego światopoglądu ${ }^{14}$. W literaturze zwraca się jednak uwagę, iż treść pojęcia „wolność sumienia i wyznania" bywa rozmaicie pojmowana. Część badaczy zdaje się utożsamiać „wolność sumienia” z ,wolnością wyznania” bądź „,wolnością religii" nie dostrzegając różnic znaczeniowych między tym terminami, albo pomijając ich istnienie. Według innych w treści pojęcia wolność sumienia i wyznania mieszczą się dwa aspekty: wewnętrzny (związany z kształtowaniem się myśli i przekonań jednostki w sprawie religii) oraz zewnętrzny (polegający na ujawnieniu myśli i przekonań dotyczących religii, a także postępowania zgodnego z przyjętymi zasadami $)^{15}$. Zwykło się uznawać, że wolność sumienia obejmuje prawo jednostki do swobodnego wyboru, kształtowania i zmiany poglądów oraz przekonań w sprawach religii. Wolność wyznania ujmuje się zazwyczaj w literaturze jako uprawnienie jednostki do uzewnętrzniania i manifestowania poglądów i przekonań w sprawach religijnych uznając ją za dopełnienie i konkretyzację wolności sumienia. Niektórzy dość nieszczę́liwie z punktu widzenia odbioru społecznego traktują wolność wyznania jako „wolność kolektywną” (według innych zbiorowa) ${ }^{16}$, gdyż „znajduje ona

ści konkretnej religii lub przekonań areligijnych oraz do wyboru wynikającego z dokonanej oceny. W literaturze zwraca się uwagę, że w sprawach religii i przekonań typową sytuacją nie jest wybór świadomy, lecz wynikający z tradycji, z wychowania domowego. Por. M. Winiarczyk-Kossakowska, Wolność sumienia i religii, „Studia Prawnicze" 2001, z. 1 (147), s. 27 i n.

${ }^{14}$ Zob. Z. Łyko, Wolność sumienia i wyznania w relacji człowiek, kościoły, państwo, w: Podstawowe prawa jednostki i ich sqdowa ochrona, red. L. Wiśniewski, Warszawa 1997, s. 82-88; M. Pietrzak, Prawo wyznaniowe, Warszawa 1993, s. 15-18; F. Mazurek, Prawo człowieka do wolności religijnej, „Kościół i Prawo” 1998, t. 5, s. 95-106; P. Sobczyk, Wolność sumienia i religii w art. 53 Konstytucji Rzeczypospolitej Polskiej z dnia 2 kwietnia 1997, „Prawo Kanoniczne” 2001, nr 3-4, s. 42.

15 J. Szymanek, Prawna regulacja wolności religijnej, „Studia Prawnicze” 2006, z. 2 (168), s. 5 i n.; M. Pietrzak, Wolność sumienia $i$ wyznania w RP (regulacje prawne i praktyka), w: tegoż, Demokratyczne świeckie państwo prawa, Warszawa 1999, s. 280 i.n.

16 J. Szymanek, Prawna regulacja wolności religijnej, s. 5 i n.; tenże Konstytucyjna regulacja stosunków państwo-kościót (ujęcie komparatystyczne), „Państwo i Prawo” 2000, nr 4, s. 2 i n.; tenże Klauzule wyznaniowe w Konstytucji RP, „Studia z Prawa Wyznaniowego" 2005, t. 8, s. 9; ks. J. Krukowski, Kościót i państwo. Podstawy relacji prawnych, Lublin 2000, s. 256 i n.; Wolność religijna w znaczeniu kolektywnym (zbiorowym, bądź instytucjonalnym) bywa pojmowana jako wolność kościołów i grup religijnych $\mathrm{w}$ ich relacji do państwa. Zob. w tym przedmiocie 
ucieleśnienie we współżyciu jednostki z innymi członkami większych społeczności"17.

Wolność sumienia i wyznania pojmowane jest bądź rozszerzająco (sensu largo), bądź zawężająco (sensu stricto). W pierwszym ujęciu zwykło sprowadzać się ją do zarówno manifestowania poglądów i przekonań religijnych, jak i do głoszenia myśli i opinii o charakterze areligijnym, a nawet antyreligijnym. W ujęciu zawężającym sprowadzana jest ona wyłącznie do przedstawiania stanowisk o charakterze religijnym oraz do tworzenia rozmaitych kościołów i związków religijnych, a także do prowadzenia wszelkiej działalności zaspakajającej potrzeby religijne. Zwolennicy takiego zawężającego pojmowania zakresu wolności sumienia i wyznania nie zawsze przy tym negują uprawnienia do propagowania poglądów areligijnych i antyreligijnych. Najczęściej uważają, że swoboda propagowania takich poglądów wynika $\mathrm{z}$ innych wolności np. słowa, prasy itd. ${ }^{18}$

Innymi słowy wolność sumienia i wyznania w sensie węższym - uznawanym najczęściej za właściwy - to wolność w sferze religijno-światopoglądowej człowieka. W sensie szerszym wolność ta pojmowana jest natomiast jako wszelka aktywność światopoglądowa, a więc zarówno w sferze wewnętrznych przekonań, jak i ich zewnętrznych praktyk religijnych i nie religijnych ${ }^{19}$. Ten ostatni sens wolności sumienia i wyznania wykształcił się w Polsce w zasadzie dopiero po II wojnie światowej pod wpływem afideistycznych orientacji światopoglądowych oraz związku z liberalnymi koncepcjami pojmowania wolności i praw człowieka. Wolność tę pojmowano nie tylko jako możliwość manifestowania swoich poglądów i przekonań religijnych, lecz także areligijnych i ateistycznych. W doktrynie toczy się spór czy słuszne jest utożsamienie wolności sumienia z wolnością wyznania, czy też należy rozróżnić

M. Granat, Granice wolności religijnej w społeczeństwie pluralistycznym, w: Kultura i Prawo. Materiały III Międzynarodowej konferencji na temat Religia i wolność religijna Unii Europejskiej. Warszawa, 2-4 września 2002, red. J. Krukowski, O. Theisen, Lublin 2003, s. 177 i n.

17 J. Osuchowski, Religia i Konstytucja, w: Państwo. Demokracja. Samorzad. Księga pamiatkowa na 65 lecie Profesora Eugeniusza Zielińskiego, red. T. Mołdawa, Warszawa 1999, s. 91; M. Pietrzak, Konstytucyjne podstawy prawa wyznaniowego, w: Konstytucyjne podstawy systemu prawa, red. M. Wyrzykowski, Warszawa 2001, s. 169 i in.

${ }_{18}$ M. Pietrzak, Prawo wyznaniowe, s. 17.

19 Ibidem. 
te wolności. Zwolennicy tego drugiego poglądu stoją na stanowisku, że wolność sumienia sprowadza się tylko do wewnętrznej aktywności religijnej, natomiast wolność wyznania to możliwość manifestowania, ujawniania swoich myśli i przekonań dotyczących tej sfery życia i postępowania zgodnie $\mathrm{z}$ nimi.

\section{Podmiotowy zakres wolności sumienia i wyznania}

Wolność sumienia i wyznania ma charakter prawa podmiotowego, czyli przysługuje każdej osobie ludzkiej niezależnie od jej obywatelstwa, miejsca zamieszkania, pobytu, płci, rasy, wykształcenia i wieku, aczkolwiek co do tego ostatniego w praktyce pojawiają się wątpliwości. Przyznać należy, że w niektórych ustawodawstwach, także europejskich wolność sumienia i wyznania łączona bywa z obywatelstwem, co wydaje się być sprzeczne z pojmowaniem jej jako atrybutu przysługującego człowiekowi, a nie obywatelowi. Warto dodać, że wolność sumienia i wyznania w ujęciu instytucjonalnym jest jednak zawsze wtórna wobec pierwotnego prawa każdego człowieka do wyznawania odpowiadającej mu religii, bądź do niewyznawania żadnej. W tej sytuacji wolność sumienia i wyznania jest wolnością, która w pierwszym rzędzie przysługuje każdemu człowiekowi. Dopiero w konsekwencji istnienia tak pojmowanej wolności pojawia się wolność sumienia i wyznania jako możliwość organizowania się według kryteriów religijnych, tworzenia kościołów i związków wyznaniowych. Wspomniana wolność tworzenia organizacji konfesyjnych ma zapewnić realizację indywidualnych praw wolnościowych poszczególnych jednostek. Tak więc, wolność sumienia i wyznania winna w minimalnym przynajmniej stopniu regulować sytuację konfesyjną jednostki oraz wspólnoty religijnej, w skład której taka jednostka może wchodzić.

O tym, że wolność sumienia i wyznania jest prawem podmiotowym świadczy chociażby orzecznictwo europejskich sądów konstytucyjnych oraz Europejskiego Trybunału Praw Człowieka w Strasburgu, które wyraźnie deklaruja, że wolność ta jest prawem podmiotowym o charakterze fundamentalnym, gwarantującym istnienie intymnej klauzuli przekonań (un cloître intime de croyances). Pod pojęciem tym zwykło się rozumieć przestrzeń indywidualnego samookreślenia (un espace d'autodétermination individuelle). W literaturze podkreśla się, że wolność sumienia i wyznania nie jest wyłącznie normą moralną, lecz wolnością człowieka 
i to bardzo specyficzna, gdyż dotyczy aktywności religijno-światopoglądowej, a więc takiej, która różni się i to w sposób bardzo istotny od wszelkich innych przejawów aktywności ludzkiej. Korzystając z tej wolności człowiek może żądać, aby inni jego wolność respektowali ${ }^{20}$. Wolność sumienia i wyznania uznawana jest jako wolność immanentnie związana z osobą ludzką, jako wolność niezbywalna i osobista. (Warto jednak zauważyć, iż niektórzy piszą, że wolność sumienia i wyznania jest przyrodzonym prawem człowieka ${ }^{21}$. Przyjmując za L. Wiśniewskim $^{22}$, iż pojęcie wolności człowieka nie jest równoznaczne $\mathrm{z}$ jego prawami, konsekwentnie także w dalszych częściach rozważań mowa będzie o wolności sumienia i wyznania nie jako o prawie - lecz o wolności). W koncepcjach wyznaniowych zwłaszcza w chrześcijaństwie, różnych zresztą odmian, wolność sumienia i wyznania wywodzi się z prawa natury z nadania Bożego oraz z godności osoby ludzkiej jako stworzonej przez Boga ${ }^{23}$. Orientacje ateistyczne, a przynajmniej fideistyczne, genezę tej wolności upatrują w godności osoby ludzkiej jako osoby myślącej, wolnej i autonomicznej, która jest członkiem określonej wspólnoty społecznej. Przedstawiciele ich stoją na stanowisku, iż wolność ta przysługuje każdemu człowiekowi bez względu na narodowość, obywatelstwo, rasę, status społeczny, światopogląd, płeć, wiek itd. ${ }^{24}$ Wolność sumienia i wyznania bywa także pojmowana jako wolność, która przysługuje nie poszczególnym jednostkom, ale jako wolność kościołów i związków wyznaniowych $^{25}$. Wolność ta ma zasadzać się na równości prawnej,

20 Z. Łyko, Wolność sumienia $i$ wyznania, s. 88.

21 Stanowisko takie prezentuje Z. Łyko, który definiuje wolność sumienia i wyznania jako prawo (przyp. mój W.S.) osobiste wszystkich jednostek ludzkich, chroniące społeczne sfery ich egzystencji oraz kościołów tych jednostek ludzkich jako wspólnot ludzi wierzących. Zob. Z. Łyko, Wolność sumienia $i$ wyznania, s. 100.

22 Zob. uwagi w podrozdziale pierwszym niniejszego rozdziału L. Wiśniewski, Prawo a wolność człowieka, s. 51-63.

23 K. Warchałowski, Prawo do wolności myśli sumienia i religii w Europejskiej Konwencji Praw Człowieka i Podstawowych Wolności, Lublin 2004, s. 54 i n.

24 A. Łopatka, Wolność sumienia i wyznania, w: Prawa człowieka. Model praw$n y$, red. R. Wieruszewski, s. 407-421, tenże, Prawo do wolności myśli, sumienia i religii, Warszawa 1995, s. 9 i n.

${ }^{25}$ M. Pietrzak, zauważa, że ,związki wyznaniowe od dawna traktowane są jako odrębne podmioty wyposażone w uprawnienia do korzystania z wolności wyznania. Zabezpieczają one realizację uprawnień indywidualnych swoich członków. Jednostka zaspokaja bowiem poważną część swoich potrzeb religijnych za pośrednictwem, bądź przy udziale struktur organizacyjno-personalnych związków wyznaniowych”. 
równości wobec prawa, równouprawnieniu wszystkich kościołów i związków wyznaniowych tzn. na posiadaniu przez nie takich samych praw bez względu na wielkość, zasługi, tradycje ${ }^{26}$. Innymi słowy ma być to wolność sprowadzająca się do tego, że wszystkie kościoły mają mieć równe szanse i równe możliwości prawne ${ }^{27}$.

W tej sytuacji wolność sumienia i wyznania jest prawem osobistym wszystkich jednostek ludzkich. Wolność ta chroni po pierwsze społeczne sfery egzystencji tych jednostek, po drugie funkcjonowanie kościołów i związków wyznaniowych jako wspólnot ludzi wierzących. Nakłada to określone obowiązki na państwo, które musi z jednej strony zapewnić każdemu obywatelowi ochronę jego indywidualnej wolności sumienia i wyznania w granicach wyznaczonych przez prawo, z drugiej zaś eliminować wszelkie formy nietolerancji stosowane przez kogokolwiek wobec jakiegokolwiek podmiotu.

Tak więc wolność sumienia i wyznania mieści się w ramach prawa podmiotowego, pojmowanego jako „możność, czy wolność działania i zachowania się człowieka", możliwość domagania się, aby inni tym działaniom nie przeszkadzali ${ }^{28}$. Nie sposób w tym miejscu przeprowadzić analizy rodowodu prawa podmiotowego ani dokonać przeglądu definicji prawa podmiotowego oraz leżących u ich podstaw teorii woli

M. Pietrzak, Prawo wyznaniowe, Warszawa 1993, s. 29. Autor ten słusznie stwierdza, że najmniejszym kolektywem, który przez współczesne ustawodawstwo uważany jest za podmiot korzystający z uprawnień wynikających $\mathrm{z}$ wolności sumienia i wyznania jest rodzina. Ibidem, s. 29. Warto jednak zauważyć, że w procesie dochodzenia tych praw powodem w postępowaniu sądowym będą tylko osoby fizyczne, a nie rodzina jako jednostka, gdyż takowa nie posiada osobowości prawnej.

${ }^{26}$ W literaturze podkreśla się, iż Kościół katolicki bardziej niż prawa dziecka akcentuje podmiotowość rodziny, uznając ją za społeczność cieszącą się własnym i pierwotnym prawem. Najważniejsze uprawnienia składające się na wolność religijną rodziny, wyliczono w Deklaracji Soboru Watykańskiego II o wolności religijnej Dignitatis humanae. Zob. H. Misztal, Kościelne pojęcie wolności religijnej a ustawa o Gwarancjach Wolności Sumienia i wyznania z 1989 r., „Kościół i Prawo" 1993, t. 11, s. 112-113.

27 K. Pyclik, Wolność sumienia i wyznania w Rzeczypospolitej Polski (założenia filozoficzno-prawne), w: Prawa $i$ wolności obywatelskie w Konstytucji RP, red. B. Banaszak, A. Preisner, Warszawa 2002, s. 440-441.

${ }_{28}$ F. Longchamps, Z rodowodu prawa podmiotowego, ,Zeszyty Naukowe Uniwersytetu Wrocławskiego, Nauki Społeczne", Prawo 8, seria A, nr 34, 1961, s. 110-117. Longchamps wywodził koncepcję prawa podmiotowego z prawa rzymskiego. Podobne stanowisko zajmował F. Zoll (senior). Zob. F. Zoll (senior), Rzymskie prawo prywatne, (Pandekta), t. IIA: Część ogólna, Warszawa-Kraków 1920, s. 18-19. 
interesu i teorii kompromisowych ${ }^{29}$. Podkreślić należy, iż w literaturze dokonując analizy formalnej pojęcia prawo podmiotowe, zwraca się uwagę, że dotyczy ono sytuacji prawnej jakiegoś podmiotu o określonych właściwościach, które odnosi się do pewnego typu zachowania lub zachowań w rozważanym systemie norm prawnych oraz kwalifikacji zachowań ze względu na normy rozpatrywanego systemu prawnego ${ }^{30}$.

S. Wronkowska-Jaśkiewicz podkreśla, że prawo podmiotowe można ująć jako wolność postępowania poszczególnego podmiotu będącą jego uprawnieniem i kompetencją do dokonywania określonych czynności, połączoną z roszczeniem w sensie procesowym ${ }^{31}$. Warto zauważyć, że na gruncie prawa cywilnego Z. Radwański wywiódł, że prawo podmiotowe to pozytywnie oceniana korzystna sytuacja jednostki w społeczeństwie. Dalej zaś zauważył, podejmując próbę definicji prawa podmiotowego, że jest to złożona sytuacja prawna wyznaczona podmiotom przez obowiązujące normy i chroniąca prawnie uznane interesy tych podmiotów. Podkreślił przy tym, że na sytuację tę składają się ,wolne - w aspekcie normatywnym - zachowania psychofizyczne lub konwencjonalne podmiotu uprawnionego, z którym sprzężone są zawsze obowiązki innego podmiotu, lub innych podmiotów przyczym $\mathrm{z}$ reguły uprawnionemu przysługuje również kompetencja do żądania, aby organ państwa dysponujący przymusem doprowadził do zrealizowania sprzężonych z prawem podmiotowym obowiązków ${ }^{32}$. Jakkolwiek koncepcja Z. Radwańskiego wydaje się być obecnie najszerzej akceptowaną, to jednak w literaturze

29 Kwestie te zostały w kompetentny sposób zanalizowane w literaturze, zob. J. Chaciński, Prawa podmiotowe a ochrona dóbr osobistych, Lublin 2004, s. 9-35; K. Gandor, Prawa podmiotowe, tymczasowe, ekspektatywy, Wrocław-Warszawa-Kraków 1968, s. 43-44; S. Riterman, Pojęcia materialne w prawie cywilnym. Studium z zakresu metodologii nauki prawa cywilnego. Rozważania ogólne, Kraków 1962, passim; S. Wronkowska, Analiza pojęcia prawa podmiotowego, „Prace Wydziału Prawa Uniwersytetu im. Adam Mickiewicza w Poznaniu”, nr 51, Poznań 1973, s. 7-8; K. Opałek, Prawo podmiotowe, Warszawa 1957, s. 215; A. Redelbach, S. Wronkowska, Z. Ziembiński, Zarys teorii państwa i prawa, Warszawa 1962, s. 143 i n. Szczególniejszą uwagę należy zwrócić na analizę pojęcia prawa podmiotowego w jego rozwoju historycznym dokonaną przez M. Pyziak-Szafnicką, zob. M. Pyziak-Szafnicka, Prawo podmiotowe, w: System prawa cywilnego, red. Z. Radwański, t. 1: Prawo cywilne, Czesść ogólna, Warszawa 2007, red. M. Safjan, Warszawa 2007, s. 671-771, tamże obszerna literatura.

30 S. Wronkowska, Analiza pojęcia, s. 17.

31 Ibidem, s. 50-56.

32 Z. Radwański, Prawo cywilne, Część ogólna, Warszawa 1999, s. 83 i 88. 
zauważa się, że raczej opisuje ona na czym polega wykonywanie prawa podmiotowego aniżeli określa jaki jest jego charakter ${ }^{33}$. Zdaniem A. Woltera prawem podmiotowym jest przyznana i zabezpieczona przez normę prawną sfera możności postępowania w określony sposób ${ }^{34}$. Według S. Grzybowskiego prawo podmiotowe to ,przyznana przez normę prawną na rzecz strony stosunku prawnego sfera możności postępowania w sposób określony w tej normie, czyli zgodnie z treścią prawa podmio-

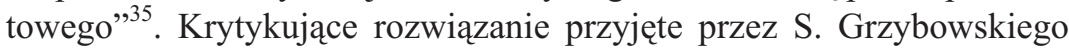
A. Szpunar podkreślał, że ,prawo podmiotowe nie sięga dalej niż interes chroniony przez ustawodawcę" 36 .

Wolność sumienia i wyznania ma postać osobistą (jest wolnością osobistą) i jako taka ma charakter podmiotowy bezwzględny, czyli jest skuteczna wobec wszystkich. Zważywszy, iż statuują tę wolność zarówno akty prawa międzynarodowego publicznego systemu ONZ, jak i normy obu systemów praw europejskich (Rady Europy i Unii Europejskiej), a także normy polskiego prawa - wypada zauważyć, że we wszystkich tych systemach prawnych wolność sumienia i wyznania jest publicznym prawem podmiotowym. Tym samym zgodnie $\mathrm{z}$ tymi wszystkimi systemami prawnymi przysługuje ona każdemu. Z punktu widzenia Międzynarodowego Paktu Praw Obywatelskich i Politycznych „każdym” jest wszelka jednostka ludzka - ale nie tylko ${ }^{37}$. Warto zauważyć, że Pakty posługują się terminem „każda istota ludzka” (art. 6), „każda osoba” (art. 10), „każdy człowiek” (art. 12), „każdy” (art. 16, 18, 19, 22) i wreszcie „każdy obywatel" (art. 25). Znacznie bardziej precyzyjna w tym zakresie wydaje się Powszechna Deklaracja Praw Człowieka, która dość jednoznacznie operuje terminem ,każdy człowiek” (art. 2, 3, 6, 8, 10, 11, 13-15, 17-29) ${ }^{38}$.

33 M. Pyziak-Szafnicka, Prawo podmiotowe, s. 689.

34 A. Wolter, Prawo cywilne, Warszawa 1972, s. 112.

35 S. Grzybowski, System prawa cywilnego, t. I, wyd. 2, Ossolineum, s. 216.

36 A. Szpunar był zdecydowanym zwolennikiem ,teorii interesu”. Poglądy swoje przedstawił w monografii poświęconej nadużyciu prawa podmiotowego i powtórzył następnie w późniejszych opracowaniach, zob. A. Szpunar, Nadużycie prawa podmiotowego, Kraków 1947, s. 18-20; tenże Ochrona dóbr osobistych, Warszawa 1997, s. 102-103.

37 Międzynarodowy Pakt Praw Obywatelskich i Politycznych otwarty do podpisu w Nowym Jorku dnia 19 grudnia 1966 r. ratyfikowany przez Polskę 3 marca 1977 r. Dz. U. 1977, Nr 38, poz. 167.

38 Prawa Człowieka. Międzynarodowe zobowiqzania Polski (Wybór dokumentów), red. A. D. Rotfeld, Warszawa 1989, s. 17-18. 
Należy już w tym miejscu podkreślić, iż treść regulacji zawartej w art. 18 Powszechnej Deklaracji Praw Człowieka jest zbieżna - lecz nie identyczna $-\mathrm{z}$ tekstem art. 18 Międzynarodowego Paktu Praw Obywatelskich i Politycznych. Nie wchodząc na razie w obszar zakresu przedmiotowego wypada zauważyć, że ujęcie zawarte w Powszechnej Deklaracji Praw Człowieka, posługującej się terminem „każdy człowiek” wydaje się bardziej precyzyjne, ale jednocześnie węższe od określenia „każdy”, do którego ucieka się Międzynarodowy Pakt Praw Obywatelskich i Politycznych. Z treści sformułowania „każdy” można by domniemywać, że jest to prawo przysługujące nie tylko jednostkom ludzkim, lecz także osobom prawnym tzn. kościołom, związkom wyznaniowym, stowarzyszeniom religijnym itd. Kwestia ta nie stała się jak dotąd przedmiotem analiz w literaturze prawniczej. Wypada jednak zauważyć, że nie tyle treść przywołanych przypisów ile przyjęte zasady legislacyjne każą traktować wspomniane normy prawa międzynarodowego jako gwarantujące sformułowane w nich wolności poszczególnym jednostkom. Należy jednak pamiętać, że z treści art. 53 ust. 2 Konstytucji oraz z art. 10 ust. 1 Karty Podstawowych Praw Unii Europejskiej, a także z art. 9 ust. 1 Europejskiej Konwencji Praw Człowieka i Podstawowych Wolności wynika, że wspomniana wolność może być ,uzewnętrzniana indywidualnie lub z innymi". Tak więc w aspekcie podmiotowym zakres ochrony obejmuje nie tylko osoby fizyczne, ale i zbiorowości. W tej sytuacji ofiarą naruszenia wspomnianych przepisów i zawartych w ich treściach wolności mogą być nie tylko osoby fizyczne, lecz także wspólnoty religijne. W zasięgu prawa krajowego może budzić wątpliwości zdolność procesowa takich wspólnot, jeżeli nie należą one do grupy tych wspólnot (kościołów bądź związków wyznaniowych), które posiadają osobowość prawną w rozumieniu prawa cywilnego. W systemie Prawnym Rady Europy podstawą roszczeń takich podmiotów będących wspólnotami wyznaniowymi może być art. 34 Europejskiej Konwencji o Ochronie Praw Człowieka i Podstawowych Wolności wymieniający wśród podmiotów uprawnionych do wnoszenia skargi organizacje pozarządowe lub grupy jednostek ${ }^{39}$.

39 Na kwestie te zwracając uwagę S. Hambura, M. Muszyński, Karta Praw Podstawowych, Bielsko-Biała 2001, s. 77. Jednak wskazują błędnie podstawę prawna, za którą uznają dyspozycję art. 25 Europejskiej Konwencji o Ochronie Praw Człowieka i Podstawowych Wolności. Ten zaś dotyczy kancelarii i sekretarzy prawnych Trybunału Praw Człowieka w Strasburgu. 
Jednobrzmiące są rozwiązania przyjęte w Europejskiej Konwencji o Ochronie Praw Człowieka i Podstawowych Wolności ${ }^{40}$ (art. 9 ust. 1) i Karcie Podstawowych Praw Unii Europejskiej ${ }^{41}$ (art. 10 ust. 1) - jak dotąd jeszcze nie przyjętej przez Polskę. Z treści ich wynika, że ustawodawca traktuje wolność myśli, sumienia i wyznania jako prawo osobiste przysługujące jednostce ludzkiej - człowiekowi. Podobnie art. 53 Konstytucji z 1997 r. zaliczając tę wolność do wolności i praw o charakterze osobistym wiąże ją z treścią art. 25 statuującego, jako zasadę ustrojową, stosunek państwa (władz publicznych) do kościołów i związków wyznaniowych $^{42}$. Wolność sumienia i religii została zaliczona do wolności

40 Konwencja o Ochranie Praw Człowieka i Podstawowych Wolności sporządzona w Rzymie 4 listopada 1950 r. zmieniona następnie Protokołami nr 3, 5 i 8 oraz uzupełniona Protokołem nr 2 ratyfikowana prze Polskę 15 grudnia 1992 r. Dz. U. 1993, Nr 61, poz. 284; uzup. Dz. U. 1995, Nr 36, poz. 175 i 176; zm. Dz. U. 1995, Nr 36, poz. 177; 1998, Nr 147, poz. 962; uzup. Dz. U. 2001, Nr 23, poz. 266; 2003, $\mathrm{Nr}$ 42, poz. 364.

${ }^{41}$ Karta Podstawowych Praw Unii Europejskiej wprowadzenie i thumaczenie, M. A. Nowicki, Zakamycze 2001, s. 29-30; zob. także S. Hambura, M. Muszyński, Karta Praw Podstawowych z komentarzem, s. 75-79.

${ }^{42}$ Warto zauważyć, że w swojej treści art. 25 Konstytucji formułuje nie jedną a pięć zasad ustrojowych określających stosunek państwa (władz publicznych) do istniejących kościołów i innych związków wyznaniowych. Zasady te zostaną omówione niżej. W tym miejscu wypada jednak zauważyć, iż w literaturze podkreśla się, że stanowią one wyraz kompromisu ,zaakceptowanego przez głównych aktorów prac konstytucyjnych" oraz, że w tym ujęciu nie są one konfliktogenne. Podkreśla to ks. J. Krukowski, Konstytucyjny system relacji między państwem a kościołem katolickim oraz innymi kościołami i zwiqzkami wyznaniowymi, w: Ustrój konstytucyjny Rzeczypospolitej Polski, red. E. Mojak, t. X, Lublin 2000, s. 101. Przypomnieć w tym miejscu wypada, że Konstytucja z 1997 r. przyjęła „technikę dyspersji materii wyznaniowej”. Problematykę instytucjonalną, relację państwa ze wspólnotami religijnymi mające charakter zasad konstytucyjnych unormowano w rozdziale Rzeczpospolita zamykając tę kwestię w art. 25 Konstytucji, a gwarancje wolności sumienia i wyznania w art. 53 zawartym w rozdziale o wolnościach i prawach jednostki. Rozwiązanie to w doktrynie jest krytykowane, zob. J. Osuchowski, Religia i Konstytucja, w: Państwo - Demokracja - Samorzq̨, Warszawa 1999, s. 92; także J. Szymanek, Konstytucyjna regulacja stosunków państwo kościót (Ujęcie komparatystyczne), PiP 2000, z. 4, s. 29; podkreśla się także że obecne przepisy zastępują „terminy mające w nauce prawa konstytucyjnego i wyznaniowego utrwaloną $\mathrm{i}$ jednoznaczną treść pojęciami niejasnymi, dwuznacznymi, czy niedookreślonymi, co może grozić chaosem interpretacyjnym", zob. M. Pietrzak, Stosunki państwo-kościót w nowej Konstytucji, PiP 1997, z. 11-12, s. 184; podobnie J. Szymanek, Stosunki wyznaniowe we wspótczesnej Polsce (elementy prawa i praktyki), w: Polska w Unii Europejskiej a stosunki wyznaniowe, red. Cz. Janik, Toruń 2005, s. 88. 
i praw o charakterze osobistym, gdyż jej wykorzystanie związane jest ściśle z osobowością człowieka, a uznanie i poszanowanie przez państwo i społeczeństwo obydwu tych wolności wynika z obowiązku ochrony godności ludzkiej ${ }^{43}$. Godność ta wyraża się m.in. „immanentnym poszu-

${ }^{43}$ Pojęcie „godności człowieka” w ostatnim czasie stało się niezmiernie popularne w rozważaniach prawników, szczególnie tych, którzy poświęcają uwagę prawu europejskiemu, głównie wspólnotowemu (unijnemu), oprócz tego zaś w środowisku teologów i filozofów. Przyczyny tego stanu rzeczy są dwojakie. Z jednej strony wydaje się to być skutkiem zwrócenia uwagi na "godność człowieka” w Karcie Podstawowych Praw Unii Europejskiej, która widzi w niej nie tylko podstawowe prawo, ale i źródło wszystkich praw człowieka'. Zob. S. Hambura, M. Muszyński, Karta Praw Podstawowych, s. 38-39. Po drugie do pojęcia tego zaczęła odwoływać się w swoich dokumentach społeczna nauka Kościoła katolickiego, zob. J. W. Gałkowski, Jan Pawet II o godności człowieka, w: J. Czerkawski, Zagadnienie godności czlowieka, Lublin 1994, s. 108 i n.; F. J. Mazurek, Godność osoby ludzkiej podstawq praw człowieka, Lublin 2001, passim, tamże obszerne omówienie literatury. Wbrew jednak pozorom pojęcie godności, jako kategoria prawna, w obszarze prawa międzynarodowego i praw człowieka nie jest nowością. Mówi o niej wyraźnie w preambule Powszechna Deklaracja Praw Człowieka z 10 grudnia 1948 r. stwierdzając: „Zważywszy, że uznanie przyrodzonej godności oraz równych i niezbywalnych praw wszystkich członków rodziny ludzkiej stanowi podstawę wolności, sprawiedliwości i pokoju na świecie...”, zob. Powszechna Deklaracja Praw Człowieka, w: K. Motyka, Prawa Człowieka. Wprowadzenie, wybór źródel, Lublin 2004, s. 125 oraz w treści art. 1, w którym zauważono: „Wszystkie istoty ludzkie rodzą się wolne i równe w swej godności i swych prawach [...]". Odwołuje się do niej także Międzynarodowy Pakt Praw Obywatelskich i Politycznych z 16 grudnia 1966 r., stwierdzając w preambule: „Zważywszy, że zgodnie z zasadami ogłoszonymi w Karcie Narodów Zjednoczonych uznanie przyrodzonej godności oraz równych i niezbywalnych praw wszystkich członków wspólnoty ludzkiej stanowi podstawę wolności, sprawiedliwości i pokoju na świecie, uznając, że prawa te wynikają z przyrodzonej godności człowieka [...]". Do sformułowań odnoszących się do godności istoty ludzkiej, a przy okazji do Karty Narodów Zjednoczonych, akcentując, że oparta jest ona na zasadzie godności i równości wszystkich istot oraz do Powszechnej Deklaracji Praw Człowieka odwołuje się w preambule Międzynarodowa Konwencja w sprawie likwidacji wszelkich form dyskryminacji rasowej z 7 marca 1966 r., (Dz. U. 1969, Nr 25, poz. 187 - załącznik). Do tych samych aktów prawnych i do pojęcia „godności” odwołują się także w preambułach konwencje: $w$ sprawie likwidacji wszelkich form dyskryminacji kobiet z 18 grudnia 1979 r., (Dz. U. 1982, Nr 10, poz. 71 - załącznik), w sprawie zakazu stosowania tortur oraz innego okrutnego, nieludzkiego lub ponizajacego traktowania albo karania z 10 grudnia $1984 \mathrm{r}$. (Dz. U. 1989, Nr 63, poz. 378 - załącznik), o prawach dziecka z 20 listopada $1989 \mathrm{r}$. (Dz. U. 1991, Nr 120, poz. 526), przy czym dwie ostatnie z nich akcentują ,przyrodzony” charakter tejże „godności”. Warto jednak zauważyć, że zarówno wspomniane Konwencje, jak i przywoływane przez nie inne akty prawa międzynarodowego, 
kiwaniem i przeżywaniem przez człowieka wartości transcendentnych”. W tej sytuacji wspomniane poszukiwanie musi być uznane, docenione i chronione. Na kwestie poszukiwania i przeżywania wartości transcendentnych zwraca także uwagę Preambuła Konstytucji ${ }^{44}$.

Warto zauważyć, że prawo podmiotowe sformułowane w treści art. 53 Konstytucji przysługuje „każdemu”, a nie tylko obywatelom. Jest rzeczą jasną, że wolność sumienia i religii ulega dodatkowemu wzmocnieniu w stosunku do obywateli państw Unii Europejskiej z mocy art. 10 Karty Podstawowych Praw Unii Europejskiej, a w odniesieniu do osób będącymi obywatelami państw Rady Europy z mocy art. 9 Europejskiej Konwencji Praw Człowieka i Podstawowych Wolności.

Niezwykle delikatną kwestią jest problem, czy dzieciom samodzielnie, nie za pośrednictwem rodziców, a nawet wbrew ich stanowisku,

nie definiują w żaden sposób pojęcia: ,godność”. Wypada w tym miejscu, z pewnym zdziwieniem skonstatować, że do pojęcia ,godność” nie odwołuje się Europejska Konwencja o ochronie praw człowieka i podstawowych wolności (Dz. U. 1993, $\mathrm{Nr}$ 61, poz. 284), ani Amerykańska Konwencja praw człowieka z 22 listopada 1969 r. Por. Wspólny standard do osiagnięcia. Stan urzeczywistnienia. W pięćdziesięciolecie Powszechnej Deklaracji Praw Człowieka z 10 grudnia 1948 r., red. T. Jasudowicz, Toruń 1998, s. 28, ani Afrykańska Karta praw człowieka i ludów z 26 czerwca 1981 r., natomiast posiłkuje się nim Powszechna Islamska Deklaracja Praw Człowieka, zob. W. Sobczak, Powszechna Islamska Deklaracja Praw Człowieka, w druku, tamże tłum. tekstu z j. arabskiego, stwierdzając: „tak jak za życia, tak po śmierci godność ludzkiego ciała winna zostać nieskalana”. Autorzy Powszechnej Islamskiej Deklaracji zdają się w tej sytuacji zwracać uwagę nie tyle na poczucie godności i cześć zewnętrzną oraz wewnętrzną, dobre imię i godność osobistą, co na szacunek dla ciała ludzkiego. Do określenia „godność” odwołuje się także Proklamacja teherańska z 13 maja 1968 r. wzywając ,wszystkie ludy i rządy do wierności zasadom wpisanym w Powszechną Deklarację Praw Człowieka oraz do podwojenia ich wysiłków na rzecz zapewnienia wszystkim istotom ludzkim życia zgodnego z ich wolnością i godnością, prowadzącego do ich dobrobytu fizycznego, umysłowego, społecznego i duchowego" oraz Akt końcowy Konferencji Bezpieczeństwa i Wspótpracy w Europie z 1 sierpnia $1975 \mathrm{r}$.

44 Stwierdzono w niej „My naród Polski - wszyscy obywatele Rzeczypospolitej zarówno wierzący w Boga, będącego źródłem prawdy, sprawiedliwości, dobra i piękna, jak i nie podzielający tej wiary, a te uniwersalne wartości wywodzący z innych źródeł...” i dodano „wszystkich, którzy dla dobra trzeciej Rzeczypospolitej tę konstytucję będą stosowali, wzywamy, aby czynili to dbając o zachowanie przyrodzonej godności człowieka, jego prawa do wolności i obowiązku solidarności z innymi...". W ten sposób treść preambuły stanowi jeszcze jedną podstawę do uznania wolności zawartych w dyspozycji artykułu 53 Konstytucji, za wolność o charakterze osobistym. 
przysługuje ochrona wolności stypizowanych w treści art. 53 Konstytucji. Doktryna stoi na stanowisku, iż dzieci z natury rzeczy nie są zdolne do samodzielnego kierowania swoimi sprawami życiowymi. Stąd prawo musi określać „status pasywny” dziecka, czyli wskazywać, kto i w jakim zakresie jest uprawniony i zobowiązany do zajmowania się jego sprawami - czyli zasady i zakres poddania władzy innych osób przede wszystkim rodziców i opiekunów. Korelatem tego uprawnienia jest obowiązek posłuszeństwa dziecka wobec rodziców. Prawo musi także określać status aktywny dziecka, zapewniający mu możliwość samodzielnego realizowania niektórych wolności i praw konstytucyjnych ${ }^{45}$. Taką wolnością jest wolność sumienia i wyznania w rozumieniu art. 48 ust. 1 w związku z art. 53 ust. 3 Konstytucji. Za przyjęciem tezy, iż jest to wolność, z której korzystać mogą osoby niepełnoletnie z punktu widzenia Kodeksu cywilnego, a więc nieposiadające zdolności do czynności prawnych, przemawia treść ust. 1 art. 53 Konstytucji, gdzie wyraźnie zawarowano, że każdemu zapewnia się wolność sumienia i wyznania. Skoro wolność ta przysługuje każdemu - to także osobom niepełnoletnim, które nie osiagnęły zdolności do czynności prawnych. O prawdziwości tej tezy upewnia dyspozycja ust. 3 art. 53 odsyłająca do treści art. 48 ust. 1 Konstytucji. Na tym tle muszą pojawić się jednak pewne wątpliwości. Po pierwsze trzeba zauważyć, że z mocy art. 53 ust. 3 Konstytucji rodzice mają prawo do zapewnienia dzieciom wychowania i nauczania moralnego i religijnego zgodnie ze swoimi przekonaniami, a więc decydującym tu, na pierwszy rzut oka, wydaje się przekonanie rodziców. Warto zauważyć, że w obrębie tym mieści się również prawo do wychowania i nauczania światopoglądu niereligijnego. Pojawia się jednak problem, czy statuowane przez ust. 3 art. 53 Konstytucji rodzicielskie prawo do zapewnienia dzieciom wychowania i nauczania moralnego i religijnego, zgodnego z przekonaniami rodziców, jest skuteczne wobec wszystkich podmiotów prowadzących szkoły publiczne i niepubliczne. Innymi słowy, czy rodzice mają możność żądania, aby szkoła zapewniała ich dzieciom wychowanie i nauczanie religijne zgodnie $\mathrm{z}$ ich wyborem. W literaturze sformułowano pogląd, że prawo to dotyczy zarówno szkół publicznych, jak i prywatnych, uznając, że zobowiązany do

45 L. Garlicki Komentarz do art. 72 Konstytucji, w: Konstytucja Rzeczypospolitej Polski, komentarz, red. L. Garlicki, t. III, Warszawa 2003, s. 4; A. Grzejdziak, Prawo do wychowania $w$ rodzinie, w: Prawa $i$ wolności obywatelskie w Konstytucji RP, red. B. Banaszak, A. Preisner, Warszawa 2002, s. 473 i n. 
realizacji tego prawa, a więc do ochrony wolności o jakiej mowa w art. 53 ust. 1, jest w szkołach prywatnych ich właściciel, a w szkołach publicznych odpowiednie władze publiczne, w których kompetencjach leżą sprawy oświatowe ${ }^{46}$. Stanowisko to wydaje się mało przekonywujące. Nie negując prawa rodziców, warto zwrócić uwagę, że sformułowanie przez nich żądań wychowania i nauczania moralnego i religijnego dla ich dzieci może w niektórych przypadkach przekraczać możliwości organizacyjne i finansowe nie tylko szkół niepublicznych, lecz także publicznych. Trudno bowiem byłoby znaleźć osobę, która podjęłaby się np. nauczania religii sikhów, bahaistów czy babistów przy konieczności takiego zorganizowania nauczania dla jednego lub dwóch uczniów ${ }^{47}$. $\mathrm{Z}$ treści art. 53 Konstytucji wywieść należy raczej prawo domagania się, aby w procesie wychowania i nauczania szkoła powstrzymywała się od naruszania sfery światopoglądowej, etycznej, płaszczyzny aksjologicznej, symboliki religijnej oraz sfery kultu. Warto zauważyć, że zd. 2 ust. 3 art. 53 odsyła do treści art. 48 ust. 1 Konstytucji nakazując, przepis ten stosować odpowiednio. Takie odpowiednie stosowanie może natrafiać jednak na poważne trudności. W zd. 1 ust. 1 art. 48 Konstytucji stwierdzono bowiem, że rodzice maja prawo do wychowania dzieci zgodnie $\mathrm{z}$ własnymi przekonaniami, ale w zd. 2 dodano, iż wychowanie to powinno uwzględniać stopień dojrzałości dziecka, a także wolność jego sumienia i wyznania oraz jego przekonania. Treść zd. 2 ust. 1 art. 48 Konstytucji pozornie „rozsądna” i przekonywująca razi użyciem terminu niedookreślonego „stopień dojrzałości”. W praktyce na tym tle moga się bowiem pojawić niezmiernie przykre dla rodziców i ich dzieci konflikty. Poddane presji nauczycieli, katechetów i kolegów dziecko, które rodzice zgodnie $\mathrm{z}$ własnymi przekonaniami pragną wychować w światopoglądzie laickim, albo w religii ewangelickiej bądź islamu może domagać

46 P. Sarnecki, Komentarz do art. 53 Konstytucji, w: Konstytucja Rzeczypospolitej Polski, komentarz, red. L. Garlicki, t. III, Warszawa 2003, s. 7.

47 Problem ten nie ma tylko charakteru teoretycznego zważywszy, że wolność określona w treści art. 53 Konstytucji przysługuje „każdemu”, a więc nie tylko obywatelom, a takimi osobami mogą być w warunkach polskich zarówno uchodźcy polityczni, jak i azylanci oraz emigranci opuszczający ojczyznę w poszukiwaniu zarobku. W kwestiach tych zob. A. Potyrała, Współczesne uchodźstwo, Poznań 2005, passim; I. Oleksiewicz, Uchodźcy w Unii Europejskiej. Aspekty prawne i polityczne, Bydgoszcz-Rzeszów 2006, passim; Wędrowcy i Migranci, red. W. Nowicka, B. Cieślińska, Kraków 2005, s. 202-218, 235-249, 262-286; J. Balicki, P. Stalker, Polityka imigracyjna i azylowa, Warszawa 2006, passim. 
się już w początkowych klasach szkoły podstawowej prawa do uczestniczenia w nauczaniu religii. W publicystyce po stronie katolickiej pojawiają się głosy, że tego rodzaju żądania są uzasadnione oraz że świadczą one o wysokim stopniu dojrzałości dziecka, które winno w tej sytuacji mieć możność realizacji swoich praw podmiotowych. Dodatkowy kłopot sprawia fakt, że zgodnie z treścią art. 48 ust. 1 zd. 2 Konstytucji wychowanie dziecka powinno uwzględniać obok stopnia dojrzałości „wolność jego sumienia i wyznania". Nie negując, iż dziecko może korzystać z wolności sumienia i wyznania nie sposób jednak nie zauważyć pewnej dyferencji między sformułowaniem „wolność sumienia i wyznania”, jakim posługuje się ustrojodawca w art. 48 ust. 1 zd. 2 Konstytucji, a wyrażeniem „wolność sumienia i religii”, które użyto w treści art. 53 ust. 1 Konstytucji. Zakładając racjonalność ustawodawcy wypada stanąć na stanowisku, iż nie są to określenia synonimiczne. Pierwsze $\mathrm{z}$ tych określeń posiłkuje się terminami utrwalonymi w dotychczasowej nauce i praktyce prawa konstytucyjnego. Drugie, jak stwierdza się w literaturze ma charakter nowy, który nie obrósł jeszcze rozważaniami doktryny ${ }^{48}$.

Konstytucja nie zakreśla czasowych granic trwania prawa rodziców do wychowania. Także pojęcie „dziecka” nie zostało w Konstytucji sformalizowane $^{49}$. W tej sytuacji, mając na względzie przytoczone wyżej

48 Por. w tym względzie M. Pietrzak, Stosunki państwo-kościót, s. 184. Podobne stanowisko wyraża J. Szymanek, Stosunki wyznaniowe we wspótczesnej Polsce, s. 88; por. także K. Krasowski, Zwiazki wyznaniowe w II Rzeczypospolitej, Warszawa-Poznań 1988, s. 54; S. Krukowski, Geneza Konstytucji z 17 III 1921, Warszawa 1977, s. 232 i 282; J. Osuchowski, Prawo wyznaniowe Rzeczypospolitej Polskiej 1918-1939, Warszawa 1967, s. 82; tenże Zagadnienie rozdziału kościoła od państwa w Polsce w latach 1918-1939, „Studia z dziejów kościoła katolickiego” 1963, R. III, nr 1 (5), s. 71; H. Świątkowski, Wyznaniowe prawo państwowe, Warszawa 1962, s. 27 i n.; J. Sawicki, Studia nad położeniem prawnym mniejszości religijnych w państwie polskim, Warszawa 1937, s. 106 i n.; W. Abraham, Konstytucja a zwiqzki wyznaniowe i Kościót, w: Nasza Konstytucja, Kraków 1922, s. 112-134.

${ }^{49} \mathrm{~W}$ treści Konstytucji występują dwie granice wieku: wiek 16 lat - wymieniony w art. 65 ust. 3 zakaz stałego zatrudnienia dzieci do lat 16 oraz wiek 18 lat - sformułowany $\mathrm{w}$ art. 70 ust. 1 związany $\mathrm{z}$ obowiązkiem pobierania nauki, a także w art. 62 ust. 1 odnoszący się do praw wyborczych i udziału w referendum. W prawie cywilnym i karnym termin „dziecko” nie jest używany. Kodeks karny posiłkuje się terminem „małoletni” (art. 208 k.k.), pod którym zgodnie z treścią art. 10 k.c. należy rozumieć osobę, która nie ukończyła 18 roku życia oraz „młodociany” (art. 115 $\S 10$ k.k.), którym jest sprawca, który w chwili popełnienia czynu zabronionego nie ukończył 21 lat i w czasie orzekania w pierwszej instancji 21 lat. Oraz wreszcie terminem „nieletni” (art. $10 \S 2$ i § 4 k.k.). Terminologia prawa karnego i cywilnego 
(przypis 50) regulacje prawne należy uznać, iż terminem granicznym, w którym kończy się konstytucyjne pojęcie dziecka jest moment jego upełnoletnienia wynikający albo z faktu ukończenia 18 roku życia, albo z faktu zawarcia związku małżeńskiego. Tego rodzaju wniosek znajduje wsparcie w treści art. 1 Konwencji o Prawach Dziecka, w myśl którego - dzieckiem w rozumieniu tej Konwencji jest każda istota ludzka w wieku poniżej 18 lat, chyba, że zgodnie z prawem odnoszącym się do dziecka uzyska ono wcześniej pełnoletniość ${ }^{50}$ oraz w art. 2 ust. 1 ustawy z dnia 6 stycznia 2000 r. o Rzeczniku Praw Dziecka - w myśl którego dzieckiem jest każda istota ludzka, od poczęcia do osiagnięcia pełnoletniości ${ }^{51}$. Podkreślić należy, iż trudno zaprzeczyć możliwości wywierania przez rodziców wpływu wychowawczego na swe „dorosłe” już dzieci - czyli dzieci, które ukończyły lat 18. Wydaje się jednak, że możliwość podejmowania przez nich tego rodzaju działań mieścić się będzie raczej w ich prawie do życia prywatnego i rodzinnego. Może też być przedmiotem roszczeń o ochronę prawną tej sfery. Odrzucić natomiast trzeba możliwość poszukiwania takiej ochrony w treści art. 48 ust. 1 zd. 1 Konstytucji. Należy przyjąć, że niepisaną zasadą konstytucyjną jest tu ustanie praw wychowawczych rodziców do wychowania dzieci zgodnie ze swoimi przekonaniami, po ukończeniu przez dziecko 18 roku życia. Po tej dacie trwają jednak ich prawa wynikające $\mathrm{z}$ treści art. 47 Konstytucji ${ }^{52}$.

oraz przyjęte tam granice wiekowe mogą mieć jedynie charakter posiłkowy. Warto pamiętać, że w myśl art. $10 \S 1$ k.c. pełnoletnim jest ten, który ukończył lat 18 . Przez zawarcie małżeństwa małoletni uzyskuje pełnoletniość art. $18 \S 2$ k.c.

50 Art. 1 Konwencji o Prawach Dziecka przyjętej przez Zgromadzenie Ogólne Narodów Zjednoczonych dnia 12 listopada 1989 r. Dz. U. 1991, Nr 120, poz. 526, zm. 2000, Nr 2 poz. 11; zob. także H. Kołakowska-Przełomiec, D. Wójcik, Ustawa $z$ dnia 26 października 1982 o postępowaniu $w$ sprawach nieletnich a Konwencja Praw Dziecka, „Studia Prawnicze” 1992, nr 3-4, s. 3 i n. Nie ma powodu, aby przypuszczać, iż ustrojodawca zamierzał odstapić od definicji dziecka w rozumieniu konwencji praw dziecka zwłaszcza, że ma ona dla Polski charakter wiążący.

51 Dz. U. 2000, Nr 6, poz. 69. Na takim stanowisku, iż dzieckiem jest już płód w łonie matki staną Trybunał Konstytucyjny w orzeczeniu z 28 maja 1997 r. (K. 26/96; OTK ZU 1997, nr 2, poz. 19, s. 152). Stanowisko to spotkało się z krytyką w literaturze, przy czym przyznawano, iż ustawodawca może przyjmować tak jak to uczyniła ustawa z 6 stycznia 2000 r. o Rzeczniku Praw Dziecka szersze pojęcie określenia „dziecko”. Zob. L. Garlicki, Komentarz do art. 72 Konstytucji, w: Konstytucja Rzeczypospolitej Polski, komentarz, red. L. Garlicki, t. III, Warszawa 2003, s. 3-4.

52 P. Sarnecki, Komentarz do artykułu 48 Konstytucji, w: Konstytucja Rzeczypospolitej Polski, komentarz, red. L. Garlicki, t. III, Warszawa 2003, s. 5. Przypadek 
Znacznie większe trudności może powodować określenie „dolnego” terminu tj. wieku, od którego dziecko w rozumieniu art. 48 ust. 1 zd. 2 może realizować swoje prawo podmiotowe w zakresie wolności sumienia i wyznania. Uznanie, że konstytucyjne pojęcie dziecka odnosi się do wszystkich, którzy nie ukończyli 18 lat zakłada istotne zróżnicowanie wewnętrzne tej klasy podmiotów, bo - w zależności od wieku i stopnia dojrzałości - status „,dziecka” musi być kształtowany w odmienny sposób. Nie ma natomiast znaczenia kryterium obywatelstwa, gdyż zarówno art. 48 jak i 53 oraz 72 Konstytucji dotyczy wszystkich dzieci, które znajdują się pod władzą Rzeczypospolitej ${ }^{53}$. W literaturze rozważany był problem czy dzieckiem jest również osoba, której okres dzieciństwa już minął, lecz która nie jest jeszcze pełnoletnia. Tę kategorię osób przedstawiciele doktryny nazywają dziećmi dorastającymi (adolescent). Podkreślając że okres dorastania jest niezwykle ważny w życiu człowieka, który w tym właśnie czasie przechodzi proces dojrzewania biologicznego i psychicznego, zwraca się uwagę, że wówczas osoba taka przestaje być dzieckiem w rozumieniu biologicznym, ale nie staje się jeszcze dorosłym, gdyż społeczeństwo nie uznaje go jeszcze za swego członka w pełni odpowiedzialnego i za pełnoprawnego obywatela ${ }^{54}$.

betanek z Kazimierza dowodzi, iż w odczuciu społecznym, a także w optyce środków społecznego przekazu rodzice mają prawo decydować o wyborach religijnych dorosłych dzieci. Część przekazów prasy drukowanej w dość histeryczny sposób komentowała bowiem fakt, iż rodzice nie mogli odebrać byłych betanek i oddać ich pod opiekę przygotowanych w tym celu duchownych, terapeutów, egzorcystów. Nie chciano przy tym zauważyć, że jakkolwiek w rozumieniu rodziców byłe zakonnice popełniły błąd, to jednak są osobami dorosłymi i pełnoletnimi i mają prawo do nieskrępowanych wyborów w zakresie wolności sumienia i wyznania. Wyrażane w relacjach telewizyjnych słowa oburzenia ze strony dziennikarzy, iż asystujący przy eksmisji funkcjonariusze Policji nie dopełnili, w ocenie tych dziennikarzy, swoich obowiązków, gdyż nie rozdzielili byłych zakonnic i nie doprowadzili siłą poszczególnych z nich do rodziców lub wręcz nie odwieźli każdej z osobna do rodzicielskiego domu dowodzą, swoistej atrofii pojęcia wolność sumienia i wyznania, która zdaniem niektórych przedstawicieli środków społecznego przekazu nie obejmuje możliwości odejścia od Kościoła katolickiego. W takich sytuacjach, jak zdają się dowodzić prezentowane stanowiska, władza rodzicielska trwa dłużej i rodzice moga decydować o wyborach religijnych swoich dorosłych, pełnoletnich, cieszących się pełnią praw, nieubezwłasnowolnionych dzieci.

53 P. Winczorek, Komentarz do Konstytucji RP z dnia 2 kwietnia 1997, Warszawa 2000 , s. 96.

${ }^{54} \mathrm{~W}$ doktrynie podkreśla się, że dziecko dorastające podlega ochronie takiej, jakiej wymaga status małoletniego. Okres dorastania dziecka liczy się na ogół od mo- 
Przewidywać należy pojawienie się na tym tle rozlicznych konfliktów, nieporozumień, a może i nawet tragedii. W chwili obecnej brak informacji, aby władze oświatowe bądź sądowe musiały rozpatrywać spór między rodzicami a dziećmi na tle żądań dziecka chcącego korzystać z wolności sumienia i wyznania i domagającego się albo możliwości wychowania w religii nieakceptowanej przez rodziców, albo wręcz przeciwnie w światopoglądzie ateistycznym. Warto jednak zauważyć, że prawa rodzicielskie, w tym prawa do wychowania dziecka zgodnie z własnymi przekonaniami, mogą być ograniczone, a nawet odebrane rodzicom. Niekoniecznie musi się to wiązać z popełnieniem przez rodziców czynów sprzecznych z dobrem dziecka, a zwłaszcza z popełnieniem przestępstwa. Pozbawienie tego typu praw może być orzeczone w razie zaistnienia okoliczności świadczących o niemożliwości lub o niepożądanym wykonywaniu całości lub części praw rodzicielskich przez ojca lub matkę. Warto pamiętać, że przyczyny odebrania tych praw zgodnie z art. 31 ust. 3 Konstytucji może określić jedynie ustawa, a orzekać w tym przedmiocie może wyłącznie sąd, co stanowi istotną gwarancję. Należy pamiętać, że z mocy art. 72 ust. 3 Konstytucji w toku ustalania praw dziecka organy władzy publicznej oraz osoby odpowiedzialne za dziecko są obowiązane do wysłuchania $\mathrm{i} \mathrm{w}$ miarę możliwości uwzględnienia praw dziecka. Bezwzględny obowiązek, to tylko obowiązek wysłuchania ${ }^{55}$.

mentu pojawienia się jego dojrzałości płciowej (puberté) do osiagnięcia dojrzałości psychicznej i uważa się go za okres przejścia od dzieciństwa do wieku dorosłego. Raport komitetu ekspertów Światowej Organizacji Zdrowia Besoins sanitaires des adolescents (Potrzeby sanitarne osób dorastających), opracowany w Genewie w dn. 28 IX-4 X 1976 r. Zauważa się, że przy ocenie dziecka jako osoby niesamodzielnej i niedojrzałej fizycznie i psychicznie należy się kierować pomocniczym kryterium potrzeby, której zaspokojenie ma na uwadze określona norma prawna. Por. T. Smyczyński, Ochrona praw dziecka, w: Prawa czlowieka. Model prawny, red. R. Wieruszewski, Wrocław-Warszawa-Kraków 1991, s. 116.

55 Unormowania dotyczące relacji praw dziecka do praw rodziców w zakresie wolności sumienia i wyznania zawarte w Konstytucji z 1997 r. są zgodne z dotyczącymi tych kwestii postanowieniami prawa międzynarodowego. Konwencja o Prawach Dziecka przyjęta przez Zgromadzenie Ogólne Narodów Zjednoczonych 20 listopada 1989 r. (Dz. U. 1991, Nr 120, poz. 526; zm. 2000, Nr 2, poz. 526) wyraźnie uznaje prawo dziecka do swobody myśli, sumienia i wyznania. Jednocześnie w art. 13 zobowiązuje państwa - strony tej umowy do respektowania praw i obowiązków „rodziców oraz, tam gdzie jest to stosowane, opiekunów prawnych, odnośnie ukierunkowania dziecka w zakresie jego praw, w sposób zgodny z rozwijającymi się zdolnościami dziecka”. Podobne rozwiązania zawiera art. 13 ust. 3 Międzynarodo- 
Pewną wskazówką dla przyjęcia dolnego progu, od którego dziecko może realizować swoje konstytucyjne prawa określone w treści art. 48 ust. $1 \mathrm{w}$ związku z art. 53 ust. 3 Konstytucji są postanowienia art. $89 \S 1$ i 2 Kodeksu rodzinnego i opiekuńczego pozwalającego dziecku, które ukończyło lat 13 na skuteczne wyrażenie zgody na zmianę nazwiska w przypadku ustalenia ojcostwa ${ }^{56}$. Kolejnym dowodem na to, że ustawodawca w sprawach dotyczących wolności i praw dostrzega w dziec$\mathrm{ku}$, a więc osobie niepełnoletniej podmiot, który może zająć stanowisko w tych kwestiach, są przepisy ustawy z dnia 15 lutego 1962 r. o obywatelstwie polskim. W myśl art. 8 ust. 7 tejże ustawy, nadanie lub rozciągnięcie obywatelstwa polskiego na dzieci, które ukończyły 16 lat następuje jedynie za ich zgodą, a zgoda na zrzeczenie się obywatelstwa na mocy art. 13 ust. 5 rozciagga się na dzieci, które ukończyły 16 lat, także jedynie za ich zgodą ${ }^{57}$. Warto przy tym zauważyć, że ustawodawca

wego Paktu Praw Gospodarczych, Społecznych i Kulturalnych z 19 grudnia 1966 r. Por. A. Łopatka, Dziecko. Jego Prawa Człowieka, Warszawa 2000, s. 78-81; A. Mezglewski, H. Misztal, P. Stanisz, Prawo, s. 63.

${ }^{56}$ W myśl ich treści - jeżeli, ojcostwo zostało ustalone przez uznanie dziecka, dziecko nosi nazwisko ojca, chyba że ten za zgodą osób, których zgoda jest potrzebna do ważności uznania, złożył przy uznaniu dziecka oświadczenie, że nosić ono będzie nazwisko matki. Jeżeli jednak w chwili uznania dziecko ukończyło już trzynasty rok życia, potrzebne jest także wyrażenie zgody przez dziecko osobiście. Sąd w wyroku ustalającym ojcostwo albo sąd opiekuńczy w wydanym później postanowieniu nadaje dziecku, na jego wniosek albo na wniosek jego przedstawiciela ustawowego, nazwisko ojca. Jeżeli dziecko ukończyło lat trzynaście, do nadania nazwiska ojca potrzebne jest także wyrażenie zgody przez dziecko osobiście. Tak więc wyraźnie z treści wspomnianego przepisu wynika, iż ustawodawca widzi w dziecku, które ukończyło 13 lat podmiot, który jest władny decydować o tak istotnej sprawie jak brzmienie swego nazwiska. Tym bardziej dziecko w tym wieku mogłoby decydować o swoich przekonaniach w zakresie wolności sumienia i wyznania. J. Ignatowicz, K. Piasecki, J. Pietrzykowski, J. Winiarz, Kodeks rodzinny i opiekuńczy z komentarzem, Warszawa 1990, s. 401-403; Kodeks rodzinny i opiekuńczy. Komentarz, red. B. Dobrzański, J. Ignatowicz, Warszawa 1975, s. 639-642.

57 T.j. Dz. U. 2000, Nr 28, poz. 353 z późn. zm. Zgodzić się należy ze stanowiskiem wyrażonym przez Wojewódzki Sąd Administracyjny w Warszawie w wyroku z dnia 21 września 2005 r. (IV SA/Wa 582/05; LEX 192910), iż w sprawach z zakresu obywatelstwa, interes prawny ma osoba, której status prawny jest przedmiotem postępowania. Należy zwrócić uwagę, że wszelkie postępowania (uzyskanie obywatelstwa w drodze aktu administracyjnego, przez oświadczenie woli, utrata obywatelstwa), prowadzone na podstawie ustawy z dnia 15 lutego 1962 r. o obywatelstwie polskim (Dz. U. 2000, Nr 28, poz. 353 ze zm.), wymagają złożenia wniosku, względnie oświadczenia przez osobę zainteresowaną rozstrzygnięciem kwestii 
stoi na stanowisku, że wiekiem właściwym dla podjęcia decyzji w kwestii nazwiska jest ukończenie 13 roku życia, a w kwestii obywatelstwa 16 roku życia ${ }^{58}$. Powodów tych decyzji trudno dociec. Wydaje się, że przyjmując $\mathrm{w}$ odniesieniu do obywatelstwa wyższą granicę wiekową ustawodawca kierował się tym, że kwestia obywatelstwa rodzi skutki praktycznie nieodwracalne.

Mając na względzie przytoczone wyżej argumenty, wskazujące na fakt, iż ustawodawca uznaje możliwość wypowiadania się dzieci w kwestiach dotyczących ich wolności i praw przed uzyskaniem pełnoletniości, wypada opowiedzieć się za tezą, iż dolnym progiem, od którego dziecko może domagać się poszanowania swoich podmiotowych wolności i praw w zakresie wolności sumienia i wyznania - jest ukończenie 13 roku życia. Nie można jednak wykluczyć, że już młodsze dziecko znajdzie się na takim etapie rozwoju dojrzałości psychicznej i emocjonalnej, że będzie w stanie w sposób całkowicie świadomy i odpowiedzialny podjąć decyzję dotyczącą swojego wyznania ${ }^{59}$. Tak czy inaczej

jej obywatelstwa polskiego. Zważywszy, że obywatelstwo jest prawem osobistym, ściśle związanym z osobą, której dotyczy, wyłączone jest inicjowanie postępowania przez inne osoby, nawet jeżeli są one krewnymi osoby, w stosunku do której ma nastąpić potwierdzenie obywatelstwa.

${ }^{58} \mathrm{~W}$ literaturze prezentowany jest pogląd, że osobą, której praw dotyka wynik postępowania, jest nie tylko ten, kto w wyniku postępowania ma interes bezpośredni. Do wzięcia udziału w sprawie uprawnia także interes pośredni. Reguła wyrażona w (art. 510 k.p.c.) ma charakter ogólny i brak jest podstaw do jej ograniczenia w postępowaniu przed sądem opiekuńczym (rodzinnym), w szczególności w sprawach dotyczących władzy rodzicielskiej. Wprost przeciwnie, w tym właśnie postępowaniu, ze względu na jego specyfikę i ochronę dobra dziecka, ustawodawca rozszerzył krąg uczestników postępowania o małoletnich, którzy w myśl art. 573 § 1 k.p.c. ukończyli 13 lat i mają zdolność procesową w postępowaniu dotyczącym ich osoby, oraz stosownie do art. $576 \S 1$ k.p.c. o osoby bliskie małoletniego. W tej sytuacji w sprawach dotyczących osoby dziecka jest ono po ukończeniu 13 lat uprawnione do osobistego działania i nie może już być reprezentowane przez rodziców lub opiekuna. Potrzeba reprezentowania dziecka występuje tylko wtedy, gdy postępowanie przed sądem dotyczy osoby niemającej ukończonych lat trzynastu. Zob. H. Dolecki, Glosa do postanowienia Sqdu Najwyższego z 16 grudnia 1997, III CZP 63/97; OSP 1997, nr 5, poz. 87.

59 Współcześnie nikt nie kwestionuje poglądu, że uprawnienie do wolności sumienia i wyznania przysługuje człowiekowi od momentu osiagnięcia pełnoletniości. W literaturze zauważa się, że obecne rozwiązania prawne opierają się na dwóch odmiennych zasadach. Pierwsza z nich przenosi uprawnienia do decydowania o korzystaniu z tego prawa przez małoletnie dzieci na rodziców lub opiekunów, druga 
treść art. 53 ust. 3 Konstytucji w zastawieniu z dyspozycją art. 48 ust. 1 Konstytucji musi budzić poważne obawy zważywszy na fakt, że w chwili obecnej niezwykle silny wpływ na wychowanie i wszelkie przekonania dziecka wywieraja, obok rodziców, nauczyciele i wychowawcy, organizacje młodzieżowe, grupy rówieśnicze. Dziecko może być obiektem zabiegów prozelityzelickich, misjonarskich. W sytuacji gdy dziecko należy do rodziny związanej z jedną z mniejszości wyznaniowych, szczególnie tych, które nie są społecznie akceptowane, takie działania mogą być szczególnie agresywne, a chęć pozyskania nowego wyznawcy bardzo silna. Nie można także wykluczyć niebezpieczeństw, które związane są z serwilistyczną wobec dominującego wyznania postawą organów władzy wykonawczej, a nawet (co chciałoby się wykluczyć) sądowej. Nie wolno nie dostrzegać także tego, że dziecko może też być obiektem manipulacji ze strony sekt religijnych. W obu przypadkach do realizacji podmiotowych wolności i praw dziecka w zakresie wolności sumienia i wyznania właściwe organy powinny podchodzić z najwyższą ostrożnością pamiętając, iż wolności te mogą znaleźć się w opozycji do wynikającego z art. 48 ust, 1 zd. 1 Konstytucji, prawa rodziców do wychowania dziecka zgodnie ze swoimi przekonaniami.

Tak więc Konstytucja nie wskazuje kryteriów, które mogłyby być pomocne przy określaniu stopnia dojrzałości dziecka niezbędnego dla samodzielnego korzystania $\mathrm{z}$ wolności sumienia i wyznania. W niewielkim stopniu doprecyzowuje to ustawa o systemie oświaty, która w art. 12 ust. 1 stwierdza, że ,publiczne przedszkola, szkoły podstawowe i gimnazja organizują naukę religii na życzenie rodziców, publiczne szkoły ponadgimnazjalne na życzenie bądź rodziców, bądź samych uczniów; po osiagnięciu pełnoletności o pobieraniu nauki religii decydują uczniowie" ${ }^{\natural 0}$. Warto, bowiem zauważyć, że użycie funktora właściwo-

przyznaje to prawo - aczkolwiek w praktyce w różnym zakresie - małoletnim od 10 do 18 roku życia. W rozwiązaniach normatywnych przejawia się ta zasada w obowiązku uzyskania zgody małoletniego na dokonanie zabiegu rytualnego, czy na zmianę religii - jeżeli dokonują jej rodzice ewentualnie na przyznaniu małoletnim, od określonego wieku uprawnienia do decydowania o uczęszczaniu na naukę religii. M. Pietrzak, Prawo, s. 29.

60 T.j. Dz. U. 2004, Nr 256, poz. 2572 z poźn. zm. Warto zauważyć charakterystyczne zmiany w treści art. 12 ust. 1 ustawy o systemie oświaty. W tekście pierwotnym (Dz. U. 1991, Nr 95, poz. 425) stwierdzano: „uznając prawo rodziców do religijnego wychowania...". Po zmianie wprowadzonej ustawą z 1 stycznia 1999 r. (Dz. U. 1998, Nr 117, poz. 759) opuszczono to sformułowanie. Nie sposób zmiany 
ściowego „bądź” pozwala jedynie na stwierdzenie, iż szkoła organizuje zajęcia z religii wtedy, kiedy życzą sobie rodzice, jak i wtedy, gdy domagają się tego uczniowie. Ustawa nie dostrzega możliwości zaistnienia konfliktu między oczekiwaniami uczniów a żądaniami rodziców. Można jedynie uznać, że wspomniany przepis wzmacnia stanowisko, iż ukończenie szkoły podstawowej stanowi wystarczający stopień dojrzałości dziecka, pozwalający mu na samodzielne korzystanie z wolności sumienia i wyznania. Posłużenie się w ustawie spójnikiem „bądź” wydaje się wysoce nieprecyzyjne i budzące poważne obawy. Spójnik „bądź” wyraża w języku prawnym dysjunkcję, a więc taką sytuację gdy ustawodawca wyklucza zastosowanie normy prawnej, gdy spełnione są obie przesłan$\mathrm{ki}^{61}$. Gdyby interpretować treść przepisu zgodnie z przyjętym założeniem oznaczałoby to, że organizuje się naukę o religii i obliguje się do uczęszczania na nią uczniów tylko wówczas, gdy byłoby to życzeniem bądź samych tylko rodziców, bądź samych tylko uczniów. Trzeba zauważyć, że jest to sprzeczne z wyrażonym w treści tego przypisu in fine stwierdzeniem, że uczniowie pełnoletni decydują o pobieraniu religii. W literaturze formułuje się przy tym wyraźnie sprzeczną z treścią art. 48 ust. 1 zd. 2 Konstytucji i ugruntowanymi poglądami przedstawicieli doktryny tezę, iż wola rodziców co do wychowania religijnego dzieci jest korelatem ich władzy rodzicielskiej, która przysługuje im w stosunku do małoletniego dziecka. Wspomniany przepis art. 12 ust. 1 ustawy o systemie oświaty traktuje się jako ściśle techniczny uznając, że kompetencje decyzyjne leżą po stronie rodziców, aż do uzyskania przez dziecko pełnoletności, a w razie sprzeczności między negatywnym oświadczeniem dziecka a pozytywnym oświadczeniem rodziców moc wiążącą należy przyznać temu ostatniemu oświadczeniu ${ }^{62}$. Wskazana teza przechodzi do porząadku dziennego nad treścią art. 47 ust. 1 zd. 2 Konstytucji traktując ją jako nieobowiązujący zbędny dodatek. Nie wyciąga również wniosków z przywołanych wyżej aktów prawnych ${ }^{63}$.

tej uznać za przypadkową. Jest ona wyraźnie wynikiem stanowiska podkreślającego nadrzędność władz publicznych.

61 Z. Ziembiński, Logika praktyczna, Warszawa 1994, s. 87.

62 M. Pilich, Ustawa o systemie oświaty. Komentarz, Warszawa 2006, s. 89 (Komentarz do treści art. 12).

${ }^{63}$ Warto zauważyć, że życzenie rodziców organizowania religii nie może mieć - jak to w praktyce niestety ma miejsce charakteru obowiązkowego, i nie może być przedmiotem składanego przymusowo na piśmie oświadczenia, gdyż jest to wyraźnie sprzeczne z treścią art. 53 ust. 7 Konstytucji. Szkoła publiczna nie może bez- 
Warto zauważyć, że art. 53 ust. 6 Konstytucji wyraźnie i jednoznacznie zabrania zmuszania „kogokolwiek” do uczestniczenia lub nieuczestniczenia w praktykach religijnych, jeśli „kogokolwiek” - to także i dzieci. W ten sposób rozszerzony został zakres wolności dziecka, którego również rodzice nie mogą zmuszać do uczestniczenia w praktykach religijnych (oczywiście praktyką religijną nie jest uczestnictwo w lekcjach religii). Podkreślić należy, że wyjątek dla rodziców w stosunku do dzieci w zakresie możliwości uczestniczenia w praktykach religijnych przewidywała Konstytucja marcowa. Obecne rozwiązanie zawarte w art. 53 ust. 6 Konstytucji wypada interpretować jako rozszerzenie praw dziecka i ograniczenie władzy rodzicielskiej. Dodatkowo wzmacnia to argumentację co do konieczności uwzględniania w procesie wychowawczym wolności sumienia i wyznania dzieci oraz ich przekonań.

W tej sytuacji opowiedzieć się należy za tezą, że swoje prawa podmiotowe w zakresie wolności określonych w treści art. 53 ust. 3 i 48 ust. 1 zd. 2 Konstytucji dziecko może realizować generalnie po ukończeniu 13 roku życia, aczkolwiek nie da się wykluczyć, że w pewnych specyficznych przypadkach z takimi uprawnionymi żądaniami będzie mogło skutecznie wystąpić wcześniej.

\section{Przedmiotowy zakres wolności sumienia i wyznania}

Przedmiotowy zakres uprawnień odnoszący się do sfery wolności sumienia i wyznania sformułowany jest niejednolicie we współczesnych ustawodawstwach. Brak także jednolitości poglądów w literaturze, co do treści tego zakresu. Sporny, co do szczegółów, jest katalog uprawnień jednostki związanych ze wspomnianym przedmiotowym zakresem. Wy-

względnie żądać od rodziców czy chcą organizowania nauki religii, gdyż taka deklaracja mogłaby być traktowana jako ujawniająca wyznawany światopogląd lub religię. Sama treść art. 12 ust. 1 zd. 1 ustawy o systemie oświaty wydaje się pozostawać w sprzeczności z art. 53 ust. 7 Konstytucji i w razie zaskarżenia do Trybunału ten niewątpliwie zmuszony będzie orzec o jej sprzeczności z Konstytucją. Nie można bowiem jednocześnie żądać sformułowania życzeń co do nauki religii i gwarantować to, że nikt nie będzie zobowiązany przez organy władzy publicznej do ujawnienia swojego światopoglądu, przekonań religijnych lub wyznania (art. 53 ust. 7 Konstytucji). Złożenie oświadczenia o żądaniu lub nie żądaniu religii ujawnia, w sposób nie budzący wątpliwości przekonania, religijne składającego takie oświadczenie. 
nika to z faktu, iż ustrojodawcy różnych państw w różny sposób ujmują wolność sumienia i wyznania. Ustrojodawca polski, jak już wspomniano, nie jest w tym zakresie konsekwentny, a antynomia między treścią artykułu 53 ust. 1 a 48 ust. 1 zd. 2 Konstytucji dość czytelna. Ustrojodawcy wyraźnie trudno zdecydować się czy gotów jest chronić wolność sumienia i religii, czy też sumienia i wyznania. Mało przekonywujące wydają się poglądy H. Misztala co do tego, że Konstytucja nie normuje wolności sumienia, a jedynie określa zakres wolności religii ${ }^{64}$. W treści art. 53 w ust. 1 zapewnia się wyraźnie ,wolność sumienia i religii”. Posłużenie się przez ustrojodawcę spójnikiem (funktorem właściwościowym) ,i” wskazuje wyraźnie na koniunkcję. Innymi słowy ustawodawca daje wyraźny sygnał, iż gotów jest chronić jednocześnie wolność sumienia i wolność religii, przy czym spójnik ten zdaje się wskazywać, że zdaniem ustrojodawcy są to dwie odrębne instytucje prawne. Przyjęcie, jak proponuje H. Misztal, iż Konstytucja nie normuje wolności sumienia, gdyż jest to wolność w zakresie wewnętrznym niemożliwym do skutecznego uregulowania za pomocą norm prawnych, nie daje się obronić na gruncie zasad logiki formalnej, będącej podstawą wykładni prawa ${ }^{65}$. Zdaniem H. Misztala istota wolności wyznania polega na świadomym wyborze światopoglądu, natomiast $\mathrm{w}$ sferę normowaną przez prawo wchodzą jedynie akty zewnętrzne podejmowane w celu zamanifestowania obranego zespołu przekonań. Przyznając, że istotnie w art. 53 ust. 2 Konstytucji określono zakres wolności religii, a w treści tego przepisu nie podjęto próby zdefiniowania wolności sumienia, to jednak można i należy przyjąć, iż wolność ta polega na zakazie zmuszania przez organy państwowe jednostki do ujawnienia swoich przekonań religijnych, filozoficznych i światopoglądowych. Prawo to jest utożsamiane z prawem do wolności psychicznej obejmujące akty myślenia, zastanawiania się oraz podejmowania decyzji w sprawach religii, a ujmując rzecz szerzej, z prawem do samookreślenia w sprawach światopoglądowych. Wolność sumienia - jak zauważa się w literaturze przejawia się w swobodzie wyboru i zmiany religii, a także w możliwości rezygnacji z wyznawania jakiejkolwiek religii i przyjęcia światopoglądu ateistycznego ${ }^{66}$. Warto

${ }^{64}$ A. Mezglewski, H. Misztal, P. Stanisz, Prawo, s. 64.

65 Z. Ziembiński, Logika praktyczna, Warszawa 1995, s. 78-79 i 85-86; także M. Zieliński, Wyktadnia prawa. Zasady. Reguty. Wskazówki, Warszawa 2002, s. 140 i n.

${ }^{66}$ J. Szymanek, Prawna regulacja wolności religijnej, „Studia Prawnicze” 2006, nr 2 (168), s. 16-18. 
zauważyć przy tej okazji, że chaos terminologiczny pogłębia fakt, że obok wolności „sumienia i religii” (ust. 1 art. 53 Konstytucji) ustrojodawca $\mathrm{w}$ tym samym przepisie posługuje się pojęciem ,nauczania moralnego i religijnego" zgodnego z przekonaniami - co interpretowane jest w literaturze jako wolność przekonań (art. 53 ust. 3 Konstytucji), a w art. 53 ust. 7 Konstytucji odwołuje się do terminu „wolność światopoglądu” (wolność przekonań religijnych lub wyznania). Dochodzi do tego, podnoszone już kilkakrotnie posługiwanie się w treści art. 48 ust. 1 zd. 2 Konstytucji określeniem „wolność sumienia i wyznania” oraz „wolność przekonań”. Natomiast w art. 25 ust. 2 Konstytucji mowa o bezstronności ,W sprawach przekonań religijnych, światopoglądowych i filozoficznych", co wydaje się być najbliższe treści art. 53 ust. 7 Konstytucji.

Trudno dociec dlaczego w Konstytucji występuje tak szeroki „rozrzut” terminów określających tę specyficzną wolność. W literaturze formułuje się domniemanie, ,że zastępując wolność wyznawania mniej pojemną wolnością religii, chciano pozyskać poparcie Kościoła katolickiego dla Konstytucji” ${ }^{\text {67. W }}$. doktrynie zauważono przy tym, że taki koniunkturalizm nie wyszedł jednak ustawie zasadniczej na dobre, bo nawet jeśli przyjąć, że pojęcia „wolność wyznania” i „wolność religii” są synonimami, to używanie synonimów nie jest zaletą ani tekstów prawnych, ani prawniczych. Co ciekawe krytyka ta formułowana jest przez ks. prof. Józefa Krukowskiego, wybitnego znawcę prawa wyznaniowego, reprezentującego, przecież katolicki punkt widzenia ${ }^{68}$. Wprowadzenie do tekstu Konstytucji dalece zróżnicowanych terminów, nie zawsze i niekoniecznie znaczących przecież to samo, nie tylko może, lecz wręcz musi doprowadzić do poważnych rozbieżności interpretacyjnych na etapie wykładni.

Niewątpliwie terminologia, jaką posługuje się art. 53 Konstytucji ma decydujący i przemożny wpływ na zakres przedmiotowy wolności sumienia i wyznania. Pojęcie wolność sumienia i wyznania było dość dobrze zadomowione w polskim języku prawnym. Wypada zauważyć, że Konstytucja marcowa posługiwała się w art. 111 pojęciem wolności sumienia i wyznania (z tym jednak, że w art. 112 mowa była jedynie

67 M. Pietrzak, Demokratyczne, świeckie państwo prawne, Warszawa 1999, s. 280-281.

68 Por. np. J. Krukowski, Konstytucyjna ochrona wolności sumienia i religii, w: Sześć lat Konstytucji Rzeczypospolitej Polskiej. Doświadczenia i inspiracje, red. L. Garlicki, A. Szmyt, Warszawa 2003, s. 159 i n. 
o wolności wyznania). Termin ten używała w art. 70 Konstytucja z 1952 r. Określeniem „wolność myśli, sumienia i wyznania” operuje zarówno Powszechna Deklaracja Praw Człowieka z 1948 r. (art. 18) ${ }^{69}$, jak i Międzynarodowy Pakt Praw Cywilnych i Politycznych z 1966 r. $\left(\right.$ art. 18) ${ }^{70}$, wreszcie Konwencja o Ochronie Praw Człowieka i Podstawowych Wolności z 1950 r. (art. 9) ${ }^{71}$. Natomiast Akt Końcowy Konferencji Bezpieczeństwa i Współpracy w Europie, zawarty w Helsinkach 1 sierpnia 1975 r., posługuje się w pkt VII w Deklaracji zasad rządzących stosunkami między państwami uczestniczącymi pojęciem „wolności myśli, sumienia, religii lub przekonań" ${ }^{, 72}$. W literaturze podkreśla się, że w terminologii międzynarodowej pojęciem zastanym, zaakceptowanym i obowiązującym jest więc pojęcie „wolności” sumienia i wyznania” (freedom of religion and beliefs, względnie la liberté confessionnlle). Warto przy tym wskazać, że czasami zwrot o wolności wyznania (freedom of beliefs) - co ciekawe, w nomenklaturze francuskiej jedyny (la liberté confessionnelle) - jest thumaczony nie tylko i nie przede wszystkim jako wolność samego wyznania, ale szerzej jako wolność przekonañ ${ }^{73}$. W literaturze podkreśla się, że posługiwanie się zwrotem wolność wyznania, bądź wolność przekonań oznacza w praktyce poszerzenie wolności religijnej o prawo do przekonań innych niż religijne, co odpowiada obecnie występującej tendencji do jak najszerszego zagwarantowania jednostce jej podstawowych praw i wolności ${ }^{74}$. Użycie przez twórców Konstytucji z 1987 r. zwrotu „wolność sumienia i religii” odczytywane jest jako odejście od przyznawania możliwie szerokich gwarancji przedmiotowych tym wolnościom ${ }^{75}$.

69 Powszechna Deklaracja Praw Człowieka, w: Prawa Człowieka. Międzynarodowe zobowiqzania Polski (wybór dokumentów), red. A. D. Rotfeld, Warszawa 1980, s. $17-18$.

70 Dz. U. 1977, Nr 38, poz. 167.

71 Dz. U. 1993, Nr 61, poz. 284 z poźn. zm.

72 Akt Końcowy Konferencji Bezpieczeństwa $i$ Wspótpracy w Europie zawarty w Helsinkach 1 sierpnia 1975 r., w: Prawa Człowieka, s. 170-171

73 M. Winczarczyk-Kossakowska, Wolność sumienia i religii, „Studia Prawnicze" 2001, nr 1, s, 23 i n.; J. Szymanek, Prawna regulacja, s. 17.

74 J. Osuchowski, Stosunki wyznaniowe $w$ Polsce na tle transformacji ustrojowej, Warszawa 1996, s, 49 i n.; Z. Resich, Międzynarodowa Ochrona Praw Człowieka, Warszawa 1981, s. 142 i n.

75 E. Schwierskott, Gwarancje wolności sumienia w systemach prawnych Polski i Niemiec, „Przegląd Sejmowy” 2003, nr 6, s. 55 i n. 
Użycie przez ustrojodawcę w treści art. 53 ust. 1 Konstytucji sformułowania „wolność religii” zaczerpniętego - jak podkreśla się w literaturze - z nauki społecznej Kościoła katolickiego ${ }^{76}$ sugeruje, że „w punkcie wyjścia za przedmiot wolności uznaje się nie jednostkę, ale religię, pojmowaną jako pewną rzeczywistość społeczną czy kulturową,"77. W literaturze stwierdza się, że wolność sumienia i religii to określenie gwarantujące jedynie wolność Kościoła ${ }^{78}$. „Wolność sumienia” i „,wolność wyznania” są terminami przyjętymi w polskiej doktrynie prawnej, znanymi zarówno w języku prawnym, jak i prawniczym - mającymi bogatą treść, obejmującą wszystkie podstawowe aspekty wolności religijnej ważne z punktu widzenia relacji prawnej ${ }^{79}$.

Zauważa się także, że ukształtowanie tekstu art. 53 Konstytucji, będące „ukłonem” w stronę koncepcji wypracowanych na gruncie katolickiej nauki społecznej, rodzi pytanie czy osoby prezentujące ateistyczne przekonania będą mogły korzystać z gwarancji przewidzianych w treści tego przepisu. Wątpliwości te pogłębia stanowisko prezentowane w literaturze, że wolności religijnej nie należy utożsamiać z indyferentyzmem religijnym, czyli postawą zobojętnienia wobec religii mającej swe źródło w założeniu, iż wszystkie religie są jednakowo prawdziwe bądź fałszywe, z relatywizmem etycznym i religijnym, według którego wszystkie wartości religijne i moralne mają charakter względny. $Z$ uznaniem autonomii sumienia polegającej na odrzuceniu obowiązku człowieka poszukiwania prawdy obiektywnej zawartej w objawieniu bożym, a uznaniu tylko prawdy subiektywnej, którą sam człowiek sobie stanowi. Wreszcie z determinizmem filozoficznym głoszącym, iż wolność człowieka polega jedynie na uznaniu obiektywnej konieczności ${ }^{80}$. Warto pamiętać, iż

${ }^{76}$ H. Misztal, w: A. Mezglewski, H. Misztal, P. Stanisz, Prawo, s. 62.

${ }^{77}$ K. Pyclik, Wolność sumienia, s. 458.

78 H. Misztal, Polskie prawo wyznaniowe, Lublin 1996, s. 46. Stwierdza się przy tej okazji, że wolność sumienia i religii to prawo obywatelskie, które zawdzięcza swoje istnienie i treść decyzji organów państwowych. H. Misztal, w: A. Mezglewski, H. Misztal, P. Stanisz, Prawo, s. 62. Stwierdzenie to jest błędne, a nawet niebezpieczne, gdyż wolność - także wolność sumienia i wyznania to nie prawo zależne od państwa, lecz wolność przysługująca nie obywatelowi, lecz człowiekowi.

79 M. Piechowiak, Wolność religijna - aspekty filozoficzno-prawne, „Toruński Rocznik Praw Człowieka i Pokoju” 1994-1995, Toruń 1996, z. III, s. 11.

${ }^{80}$ J. Krukowski, Kościót i państwo. Podstawy relacji prawnych, Lublin 2000, s. 88 . 
w myśl katolickiej nauki społecznej wolność sumienia i religii jest „pierwszym i niezbędnym prawem osoby ludzkiej”" ${ }^{\prime 1}$. W Deklaracji o Wolności Religijnej stwierdzono, że „Obecny Sobór Watykański oświadcza, że osoba ludzka ma prawo do wolności religijnej [...]. Poza tym oświadcza, że prawo do wolności religijnej jest rzeczywiście zakorzenione w samej godności osoby ludzkiej, którą to godność poznajemy przez objawione Słowo Boże i samym rozumem"

Warto zauważyć, że pojęcie godności w ostatnim czasie, począwszy od Soboru Watykańskiego II, zaczęło się pojawiać w dokumentach Kościoła katolickiego. Szczególniejszą uwagę poświęca mu Gaudium et spes $^{83}$ oraz encyklika Redemptor hominis ${ }^{84}$. W myśli nauki społecznej Kościoła katolickiego, godność osoby ludzkiej może być rozpoznawana w ujęciu filozoficznym i teologicznym, w aspekcie przyrodzonym i nadprzyrodzonym ${ }^{85}$. Godność człowieka jest w tej sytuacji jednocześnie kategorią teologiczną, filozoficzną i prawną. W literaturze zwraca się uwagę, iż badacze analizujący problem godności wywodzą ją z tre-

81 Dokument Stolicy Apostolskiej o wolności religijnej 1980, cyt. za J. Krukowski Kościót i Państwo, s. 91.

${ }^{82}$ Sobór Watykański II, Deklaracja wolności religijnej dignitatis humane 1965. Problem godności w nauce społecznej Kościoła katolickiego stał się przedmiotem rozlicznych rozważań. W kwestii tej zob. M. Piechowiak, Pojęcie praw człowieka, w: Podstawowe prawa jednostki i ich sqdowa ochrona, red. L. Wiśniewski, Warszawa 1997, s. 7-37; J. Krukowski, Godność czlowieka podstawa konstytucyjnego katalogu praw i wolności jednostki, w: Podstawowe prawa jednostki, s. 38-50; tenże, Godność ludzka podstawa praw $i$ wolności czlowieka w umowach międzynarodowych, w: Kultura i prawo, t. I: Podstawy jedności europejskiej, Lublin 1999, s. $179-200$.

83 J. Majka, Etyka społeczna i polityczna, Warszawa 1993, s. 20-22; G. Filibeck, Prawa osoby w świetle Soboru Watykańskiego II, „Społeczeństwo. Studia, Prace Badawcze, Dokumenty z Zakresu Nauki Społecznej Kościoła" 1997, nr 3, s. 486 i n.; Deklaracja o wolności ludzkiej „Dignitatis humanae”, w: Sobór Watykański II, Konstytucje, dekrety, deklaracje, Poznań 1968, s. 415 i n.; K. Wojtyła, Osoba i czyn oraz inne studia antropologiczne, Lublin 1994, s. 419 i n.

${ }^{84}$ J. Kowalski, D. Sikorki, G. Ślęzak, Poznać człowieka w Chrystusie. Jan Pawet II o godności ludzkiej, Częstochowa 1983, passim; Jan Paweł II, Christifideles laici, Wrocław 1989, s. 37; zob. F. J. Mazurek, Godność osoby ludzkiej podstawa praw człowieka, Lublin 2001, s. 133-142.

85 Por. F. J. Mazurek, Godność osoby, s. 140. Według Katechizmu Kościoła katolickiego, „Godność osoby ludzkiej ma podstawę w stworzeniu jej na obraz i podobieństwo Boże”, zob. Katechizm Kościola katolickiego, Poznań 1994, s. 405 . 
ści religijnych ${ }^{86}$ bądź z prawa natury ${ }^{87}$. W tym ostatnim ujęciu godność wynika z moralnej autonomii (samookreślenia) człowieka. W ostatnich czasach zwraca się uwagę na kontekst społeczny „godności”. Według większości, jest ona wartością wrodzoną niezbywalną, jednak niektórzy zdają się uznawać jej wtórność i nabywalność ${ }^{88}$. W doktrynie wyróżnia się aspekt: teologiczny, metafizyczny, etyczny i ontologiczny godności. $\mathrm{Na}$ tym tle analizuje się koncepcje chrześcijańskie (teologiczne), racjonalistyczne, marksistowskie, socjologiczne i behawioralne. W zasadzie wszystkie te ujęcia traktują godność człowieka, jako kategorię trwała, uniwersalną, przysługującą człowiekowi z tej racji, że jest osobą ludzką. Podkreśla się także, że wraz z rozwojem cywilizacyjnym ulega ona wzbogaceniu, a jej zakres rozszerza się ${ }^{89}$.

Wolność religijna w ujęciu nauki społecznej Kościoła katolickiego wyraża się w aspekcie wewnętrznym i zewnętrznym. W aspekcie wewnętrznym wolność religijna to wolność sumienia, czyli zdolność osoby

${ }^{86} \mathrm{Na}$ takim stanowisku stali m.in. Tomasz z Akwinu, Pico della Mirandola, a współcześnie J. Maritain oraz w nauczaniu społecznym: Jan XXIII, Paweł VI, Jan Paweł II. Por. J. Mazurek, Godność osoby, s. 17 i n.; tenże, Pojęcie godności człowieka. Historia i miejsce $w$ projektach Konstytucji III Rzeczypospolitej, „Rocznik Nauk Prawnych KUL" 1996, t. VI, s. 34 i n.; tenże, Prawa człowieka w nauczaniu społecznym Kościoła (od papieża Leona XIII do papieża Jana Pawła II), Lublin 1991, s. 18; tenże, J. Maritaina koncepcja praw człowieka, w: Jacques Maritain prekursor soborowego humanizmu, red. S. Kowalczyk, S. Balawajder, Lublin 1992, s. 165 i n.; E. Soto-Klass, Starotestamentowe podstawy godności człowieka, w: Godność człowieka jako kategoria prawa (Opracowania i materiały), red. K. Complak, Wrocław 2001, s. 55-64; J. W. Gałkowski, Jan Pawet II o godności człowieka, w: Zagadnienie godności człowieka, red. J. Czerkawski, Lublin 1994, s. 108; J. Maritain, Osoba i społeczeństwo, w: Wprowadzenie do filozofii J. Maritaina, S. Kowalczyk, Lublin 1992, s. 42-44.

87 Stanowisko takie zajmowała część filozofów greckich: Hezjod, Heraklit, stoicy (Cyceron), a także J. Kant. Por. M. J. Meyer, Idea godności u Kanta a współczesna myśl polityczna, w: Godność człowieka jako kategoria, op. cit., s. 43-53; A. Łopatka, Prawa człowieka refleksje wokót pojęcia, w: Teoria prawa, filozofia prawa współczesne prawo i prawoznawstwo, Toruń 1998, s. 148; tenże, Prawo natury a świadomość prawna, w: Powrót do prawa ponadustawowego, red. M. Szyszkowska, Warszawa 1999, s. 112; zob. także P. Kamela, Koncepcja minimalna treści prawa natury H. L. A. Harta i jej oddziatywanie w Polsce, w: Powrót do prawa, op. cit., s. 301-314.

${ }_{88}$ M. Piechowiak, Filozofia praw człowieka, Lublin 1999, passim; F. J. Mazurek, Godność osoby ludzkie, s. 13-15.

${ }^{89}$ L. Garlicki, Komentarz do art. 30 Konstytucji, w: Konstytucja Rzeczypospolitej Polskiej. Komentarz, Warszawa 2003, s. 3-4. 
ludzkiej do podjęcia moralnego wyboru zgodnie z nakazem sumienia. Wolność religijna $\mathrm{w}$ aspekcie wewnętrznym obejmuje zdolność człowieka do poznania prawdy oraz obowiązek przyjęcia tej prawdy, a także odczucie obowiązku postępowania zgodnie z poznaną prawdą. Wolność religijna $\mathrm{w}$ aspekcie zewnętrznym obejmuje: wolność do uzewnętrznienia swoich przekonań w życiu prywatnym i publicznym oraz wolność od przymusu zewnętrznego w manifestowaniu swoich przekonań religijnych. Podkreślając, że wolność religijna w aspekcie zewnętrznym podlega ochronie prawnej zauważa się, że ochrona ta może być rozpatrywana w sensie pozytywnym i negatywnym. W sensie pozytywnym wolność religijna polega na swobodnym manifestowaniu swoich przekonań religijnych $^{90}$. W sensie negatywnym prawo do wolności religijnej polega na wolności od przymusu ze strony innych jednostek grup społecznych oraz władz publicznych. Oznacza to, że w materii religijnej nikogo nie można zmuszać wbrew jego sumieniu, ani nikomu nie można stawiać przeszkód w działaniu zgodnym z jego sumieniem, czyli takim działaniem, które on sam uznał za swój obowiązek.

Ustawodawca polski w treści art. 53 ust. 1 Konstytucji afirmuje więc w tej sytuacji koncepcje katolickiej nauki społecznej stwierdzając, że zapewnia się „wolność sumienia” wyraźnie mówi, że gotowy jest objąć ochroną ten aspekt wolności religijnej, który zgodnie z nauką społeczną Kościoła katolickiego ma charakter wewnętrzny. Natomiast określenie „wolność wyznania” odnosi się do wolności religijnej w aspekcie zewnętrznym. Warto zauważyć, że w tej sytuacji ustrojodawca zapewniając „wolność sumienia" - czyli wolność religijną w aspekcie wewnętrznym chce chronić zdolność człowieka do poznania prawdy i odczucie obo-

90 W literaturze zwraca się uwagę, iż według stanowiska Vatikanum II prawna ochrona wolności religijnej w aspekcie zewnętrznym w sensie pozytywnym dotyczy zachowań ludzi wobec siebie ze względu na prawdę o Bogu. Przedmiotem ochrony są relacje między ludźmi, a nie wartości duchowe. Jak zwraca na to uwagę J. Krukowski przed Soborem Watykańskim II głoszono, że ,tylko prawda ma prawo do wolności” - prawdą zaś było to, co głosił Kościół katolicki. W chwili obecnej nauka społeczna Kościoła stoi na stanowisku, że zakres przedmiotowy ochrony wolności obejmuje takie formy ludzkich zachowań, przez które człowiek, zgodnie z nakazem swojego sumienia, określa swój stosunek do Boga w życiu osobistym i społecznym oraz prywatnym i publicznym. J. Krukowski, Kościót i Państwo, s. 92. Stanowisko takie jawi się jako istotne poszerzenie zakresu wolności religijnej aczkolwiek wydaje się ono być dalekie od akceptacji możliwości, uznania prawa innych wierzeń. Kościół katolicki stwierdza, że ,,prawdą” jest tylko to co naucza. 
wiązku postępowania zgodnie z poznaną prawdą. Skoro zaś prawdą, według nauki społecznej Kościoła katolickiego jest tylko to co wynika z jego nauczania - to można interpretować treść art. 53 ust. 1 Konstytucji jako deklarację chronienia prawdy, jaką głosi Kościół katolicki. Jakkolwiek należy podkreślić, że zgodnie z treścią nauki Kościoła katolickiego wolność religijna w aspekcie wewnętrznym - czyli wolność sumienia nie musi być chroniona prawnie, to jednak treść zawarta w art. 53 ust. 1 Konstytucji może prowadzić niektórych do wniosku, że jest to deklaracja ochrony wolności sumienia w rozumieniu nauki społecznej Kościoła katolickiego, ochrona prawdy głoszonej przez ten Kościół. Oczywiście taka supozycja wydaje się być sprzeczna z zamierzeniami ustrojodawcy, ale nie można wykluczyć, iż nie pojawi się w przyszłości.

Przedmiotowy katalog uprawnień jednostki wynikający z wolności sumienia i wyznania jest dość obszerny i jak się wydaje jasno zdefiniowany w literaturze. Powyższe uwagi, co do zakresu terminologicznego „wolność sumienia i religii” jakim posiłkuje się art. 53 ust. 1 Konstytucji, nakazują jednak rozważenie czy katalog ten mieści się w treści tego sformułowania oraz w uściślających tę wolność ust. 2-7 Konstytucji. W doktrynie zauważa się, że do zakresu przedmiotowego wolności sumienia i wyznania należy: uprawnienie do tworzenia nowych związków wyznaniowych, prawo do zmiany wyznania i przekonań religijnych, prawo do milczenia w kwestiach sumienia i wyznania, prawo do manifestowania przekonań w sprawach religijnych w tym nauczania oraz postępowania zgodnie z ich nakazami, a więc praktykowanie, uprawianie kultu, modlenie się, uczestniczenie w obrzędach, prawo do odmowy obowiązku nakazanego przez ustawę z powodu sprzeciwu sumienia (tzw. klauzula sumienia), prawo do ochrony przekonań w sprawach religijnych.

Prawo do tworzenia nowych związków wyznaniowych wydaje się dobrze osadzone $\mathrm{w}$ prawie międzynarodowym publicznym. W literaturze stwierdza się, że wynika ono z indywidualnej wolności sumienia i wyznania, na straży której stoi art. 9 Europejskiej Konwencji o Ochronie Praw Człowieka i Podstawowych Wolności. Warto jednak zauważyć, że z treści tego przepisu nie wynika wprost wolność bądź prawo tworzenia nowych związków wyznaniowych. W doktrynie wywodzi się je z uchwały Komitetu ONZ z 20 lipca 1993 r. w sprawie interpretacji art. 18 Międzynarodowego Paktu Praw Obywatelskich i Politycznych oraz z uchwał Zgromadzenia Parlamentarnego Rady Europy z 1992 i 1999 r. podjętych w związku z dyskusją dotyczącą nowych ruchów religijnych (sekt) oraz z uchwały tegoż Zgromadzenia w sprawie toleran- 
cji religijnej w demokratycznym społeczeństwie ${ }^{91}$. Przywołane uchwały sprzeciwiają się jednoznacznie i konsekwentnie wydawaniu specjalnych ustaw przeciwko nowym ruchom religijnym uznając, że może stać się to instrumentem ograniczania wolności religijnej. Nakłaniają one państwa będące członkami wspomnianych organizacji międzynarodowych, aby powstrzymały się od prób określania co jest, a co nie jest religią - gdyż grozi to zaangażowaniem państwa w sprawy religijne i utratą neutralności. Zalecaja, aby zarejestrowanym związkom wyznaniowym przyznawany był taki status korporacji, z jakiego korzystają dotychczas istniejące. W uchwałach wskazuje się, że zadaniem państwa jest przeciwstawianie się rozpowszechnianiu nieprawdziwych informacji o nowych ruchach religijnych także przez system nauczania szkolnego. Dostrzegając niebezpieczeństwo, jakie niesie pojawianie się nowych ruchów religijnych ${ }^{92}$ wskazywano, że monitoring ich powinien być prowadzony przez ośrodki niezależne od władz państwowych oraz od dominujących w społeczeństwie związków wyznaniowych, aby zapewnić w ten sposób obiektywność i rzetelność przekazywanych informacji ${ }^{93}$.

91 M. Pietrzak, Polskie prawo wyznaniowe wobec standardów Unii Europejskiej, w: Polska w Unii Europejskiej a stosunki wyznaniowe, red. Cz. Janik, Toruń 2005, s. 21; M. Rynkowski, Status prawny kościołów i zwiqzków wyznaniowych w Unii Europejskiej, Warszawa 2004, s. 187 i n.

${ }_{92} \mathrm{~W}$ kwestii nowych ruchów religijnych zob. A. Szarszewski, Antykulturowy wizerunek nowych ruchów religijnych $w$ perspektywie rzeczywistości medialnej, Poznań-Oploe 2010; E. Barker, Nowe ruchy religijne, Kraków 1997; N. Libiszowska-Żółtkowska, Konwertyci nowych ruchów religijnych, Lublin 2003; T. Doktór, Nowe ruchy religijne w Europie wschodniej, „Przegląd Religioznawczy” 1997, nr 4, s 66; K. Urban, Z problematyki legalizacji nowych zwiazków religijnych $w$ Polsce w latach 1977-1997, „Nomos” 1998, nr 22-23, s. 97; C. G. Trocchi, Nowe ruchy religijne, Kraków 2002.

93 Problematyka tworzenia nowych związków wyznaniowych wiąże się z delikatną sferą tworzenia tzw. sekt, które są problemem nie tylko dla Kościoła katolickiego, lecz także budzą obawy prawosławia, znaczącej części protestantów oraz zwolenników islamu. Termin sekta pochodzi z języka łacińskiego i oznacza sposób życia, stronnictwo. Oznacza z jednej strony grupę religijną, która oderwała się od któregoś z wielkich kościołów i przyjęła własne zasady organizacyjne, stając się odłamem wyznaniowym jakiejś religii, w drugim znaczeniu sekta to jedynie grupa izolująca się od ogółu. Niektórzy dopatrują się istoty sekty w jej odłączeniu od kościoła inni w zasadniczym jej przeciwieństwie do organizacji kościelnej w ogólności. Wskazuje się, że sekta to grupa wyznaniowa, która oddzieliła się od danej religii, jest hermetycznie zamknięta przed innymi, charakteryzuje ją wyjątkowa rola przywódcy i agresywny prozelityzm. W kwestii pojęcia i charakteru sekty zob. M. Szo- 
W tej sytuacji przedmiotowe prawo tworzenia nowych związków wyznaniowych jawi się jako niekoniecznie jednoznaczne w aspekcie międzynarodowym, w szczególności zaś europejskim - w obu jego systemach (Rady Europy i Unii). Konstytucja nie formułuje wprost tego prawa aczkolwiek z treści art. 53 ust. 2 zdaje się wynikać, że ustawodawca pragnie chronić wolność w zakresie wyznawania lub przyjmowania religii. Określenie przyjmowania można jednak interpretować zawężająco, jako przystępowanie do religii już istniejących oraz rozszerzająco jako możność tworzenia nowych religii. Powstawanie nowych odłamów religijnych, zdobywanie przez nich wyznawców jest zjawiskiem, które zdaje się zasługiwać na ochronę z punktu widzenia wartości, jakie legły u podstaw art. 53 Konstytucji. Z drugiej jednak strony powstawanie takowych sekt może prowadzić do zjawisk społecznie negatywnych i ograniczać prawnie chroniony zakres wolności człowieka.

Reasumując wypada raz jeszcze stwierdzić, że treść art. 53 Konstytucji zarówno w całości, jak i w ust. 3 nie statuuje wyraźnie możliwości „założenia” nowej religii, stanowiąc jedynie o „możliwości wyznawania lub przyjmowania religii według własnego wyboru". Sugeruje to ograniczenie wolności sumienia i religii jedynie do już istniejących wyznań. W literaturze prawniczej przyznaje się jednak, iż wolność sumienia i religii, w ujęciu art. 53, pozwala na uznanie, że „wolność wyznania religii według własnego wyboru” mieści również w sobie „wybór nowej, przez

stak, Sekty destrukcyjne. Studium metodologiczno-kryminalistyczne, Zakamycze 2001, s. 56-57; E. M Guzik-Makaruk, Sekty religijne w Polsce, Warszawa 2004, s. 31-45, tamże analiza obszernej literatury. W obszarze prawa Unii Europejskiej pojęcie sekty wiąże się z pracami Parlamentu Europejskiego w tym w szczególności z tzw. raportem Cottrella z 1984 r., w którym apelowano o: wymianę informacji na temat problemów związanych z działalnością nowych ruchów religijnych, w szczególności w kwestiach dotyczących sposobu uzyskiwania przez te ruchy dochodów i zwolnień podatkowych, poszukiwania osób zaginionych, badanie sposobu w jaki gwałcone jest prawo do wolności osobistej adeptów tych ruchów, oraz utworzenie organizacji, które ofiarowywałyby pomoc osobom opuszczającym te ruchy. W raporcie wskazano, że istniejące luki prawne w krajach będących członkami Wspólnot Europejskich powodują, że działalność sekt zabroniona w jednym kraju jest legalna w innym. W podjętej w 1996 r. uchwale o sektach Parlament Europejski podkreślił, że działalność sekt jest stale rozpowszechniającym się fenomenem, potwierdzając jednocześnie prawo do wolności wypowiedzi, wyznania i religii. Zaapelował o podjęcie kroków, które będą przeciwdziałać naruszeniu prawa przez nowe ruchy religijne. Wskazał także na konieczność zawieszania statusu związku wyznaniowego w odniesieniu do tych nowych ruchów religijnych, które prowadzą podejrzane interesy. 
siebie głoszonej religii". Nie sposób się jednak zgodzić z poglądem, iż art. 9 Europejskiej Konwencji o ochronie Praw Człowieka i Podstawowych Wolności, tak w ust. 1 jak i w ust. 2, zawiera expressis verbis możliwość zmiany religii ${ }^{94}$.

Katalog przedmiotowych uprawnień mieszczących się w ramach określonej w art. 53 Konstytucji wolności sumienia i religii nie wymienia wyraźnie prawa do zmiany wyznania. Przewiduje je wyraźnie i jednoznacznie art. 9 Europejskiej Konwencji o Ochronie Praw Człowieka i Podstawowych Wolności, którego treść w tym zakresie nie została recypowana przez Konstytucję. Zmiana wyznania musi mieć oczywiście charakter dowolny, pozbawiony wszelkich form przymusu fizycznego bądź psychicznego ze strony władz państwowych, wyznaniowych bądź osób fizycznych. Dotyczy to zarówno pozyskiwania nowych członków, jak i powstrzymywania ich od opuszczenia kościoła, bądź związku wyznaniowego. W literaturze podkreśla się, że wszelkie formy ostracyzmu społecznego ze strony bliższego bądź dalszego otoczenia takich osób powinny być zwalczane, jako przejaw nietolerancji bądź dyskryminacji. Zmiana wyznania nie może bowiem pociągać za sobą żadnych sankcji karnych, cywilnych ani łączyć się z ograniczeniem praw cywilnych czy politycznych jednostki ${ }^{95}$. Podkreśla się, że integralność i autonomia osoby nie może być jedynie jednorazowym wyborem religii czy przekonania. Wolność zmiany religii czy przekonania to wolność trwała uniemożliwiająca ciagłe korzystanie z możliwości kształtowania swojej tożsamości. Oznacza to, że każdy ma prawo odejść od wyznawanej religii, przyjać inną lub pozostać bez żadnej. Z natury rzeczy wynika, że wolność zmiany religii implikuje również prawo do jej niezmieniania i pozostania przy swoich dotychczasowych przekonaniach ${ }^{96}$.

94 P. Sarnecki, Komentarz do art. 53 Konstytucji, w: Konstytucja Rzeczypospolitej Polskii Komentarz, red. L. Garlicki, t. 3, Warszawa 2003, s. 5.

95 M. Pietrzak, Polskie prawo wyznaniowe wobec standardów, s. 22; por. Uwagi ogólne Komitetu Praw Człowieka ONZ, nr 22(48) dotyczące art. 18 Międzynarodowego Paktu Praw Obywatelskich i Politycznych z 16 grudnia 1996 r., przyjęte 20 lipca 1993 r, w: Wolność religii. Wybór materiałów, dokumentów, orzecznictwo i oprac. T. Jasudowicz, Torun 2001, s. 71; por. także L. Wiśniewski, Wolność sumienia $i$ wyznania $w$ Europejskiej Konwencji Praw Człowieka i w prawie polskim, „Państwo i Prawo" 1992, nr 4, s. 17, C. Evans, Freedom of religion dunder the European Convention on Human Rights, Oxford 2001, s. 97 i n.

96 J. Krukowski, Ochrona wolności religijnej w umowach międzynarodowych, „Roczniki Nauk Prawnych” 1993, nr 3, s. 57. Wolność opuszczenia religii odnosi się 
Wolność zmiany religii lub przekonań jest naturalną konsekwencją wolności sumienia i wyznania, która chroni przed przymusem przynależenia do określonych religii lub utożsamiania się z określonymi przekonaniami i indoktrynacją ze strony państwa. Możliwość zmiany religii i przekonań jest zarówno sensem, jak i gwarantem wspomnianych wolności. Warto zauważyć, że nie kwestionuje się możliwości zmiany religii w literaturze stojącej na gruncie społecznej nauki Kościoła ${ }^{97}$. Wolność zmiany wyznania (według nauki społecznej Kościoła katolickiego) nie podlega ograniczeniom wynikającym z treści art. 9 ust. 2 Europejskiej Konwencji o Ochronie Praw Człowieka i Podstawowych Wolności, ani tym, które przewiduje art. 53 ust. 5 Konstytucji, dla uzewnętrznienia religii, gdyż odnoszą się one jedynie do uzewnętrzniania wyznania lub przekonań, a w porządku pojętym przez Konstytucję religii. Pozwala to stwierdzić, że wolność ta niezależnie czy zostanie potraktowana jako wolność zmiany wyznania czy przekonań, czy jako wolność zmiany religii, ma charakter absolutny i nie może być w żaden sposób ograniczona przez państwo ${ }^{98}$.

Z wolnością do zmiany wyznania i przekonań (religii) wiąże się w katalogu zakresu przedmiotowego wolność sumienia i wyznania (religii) prawo do milczenia w tych kwestiach. W treści ust. 7 art. 53 Konstytucji stwierdzono jednak, że nikt nie może być obowiązany przez

do wszystkich religii i przekonań, jakkolwiek w literaturze poddawano w watpliwość to, czy obejmuje wyznawców islamu, którzy jakoby nie mogą wyprzeć się swojej wiary. To ostanie stanowisko nie ostało się jednak pod naporem krytyki, zob. M. Talbi, Plaidoyer pour un Islam moderne, Brouwer 1998, s. 93-94.

${ }^{97}$ K. Warchałowski, Prawo do wolności myśli sumienia i religii w Europejskiej Konwencji Praw Człowieka i Podstawowych Wolności, Lublin 2004, s. 97. Wolność zmiany religii bądź przekonań była przedmiotem poważnych kontrowersji na forum ONZ z uwagi na stanowisko krajów arabskich, nie budziła natomiast najmniejszych wątpliwości podczas prac nad Europejską Konwencją o Ochronie Praw Człowieka i Podstawowych Wolności, zob. C. Evans, Freedom of religion..., s. 97. Pamiętać jednak należy, że prawodawstwo szwedzkie aż do 1950 r. zabraniało opuszczania kościoła państwowego, jeżeli nie przechodziło się do innej chrześcijańskiej wspólnoty religijnej; zob. K. J. Partsch, Die Rechte und Freiheiten der Europäischen Menschenrechtskonvention, w: Die Grundrechte, red. K. A. Betternmann, F. L. Neumann, H. C. Nipperdey, t. I/1, Berlin 1966, s. 428.

98 J. A. Frowein, Article 9, w: La Convention Européenne des Droits de l'Homle - Commentaire artele par article, red. L. E. Pettiti, E. Decaux, P. H Imbert, Paris 1998, s. 353; por. D. Gomein, D. Harris, L. Zwaak, Law and the European Social Charter, Strasburg 1996, s. 271. 
organy władzy publicznej do ujawnienia swojego światopoglądu, przekonań religijnych lub wyznania. W pewnym sensie gwarantuje to wspomniane prawo do milczenia w kwestiach wyznaniowych. Zarówno Konstytucja, jak i art. 9 Europejskiej Konwencji o Ochronie Praw Człowieka nie formułuje wprost tej wolności. Wbrew poglądowi prezentowanemu w literaturze $^{99}$ nie wyraża go także art. 18 ust. 2 Międzynarodowego Paktu Praw Obywatelskich i Politycznych z 16 grudnia 1996 r. Jakkolwiek ani Konstytucja ani akty prawa międzynarodowego nie formułują wprost prawa do milczenia w kwestiach sumienia i wyznania, to jednak prawo takie da się wywieść z treści art. 18 ust. 2 Międzynarodowych Paktów Praw Obywatelskich i Politycznych, jak i z art. 9 ust. 1 Europejskiej Konwencji Praw Człowieka i Podstawowych Wolności, a także z treści art. 53 ust. 2 Konstytucji. Prawo do milczenia w sprawach sumienia, wyznania i religii nakłada na organy władzy publicznej obowiązek powstrzymania się od żądania, aby obywatel bądź osoba zamieszkująca na jakimś terytorium ujawniła swoją religię, bądź światopogląd. W konsekwencji władze publiczne nie mogą żądać, aby obywatel przy jakiejkolwiek okazji był zmuszany do ujawnienia swojego wyznania, religii bądź światopoglądu. Niedopuszczalne jest też wskazywanie w jakichkolwiek dokumentach (np. paszportach, dowodach osobistych) religii posiadaczy takiego dokumentu ${ }^{100}$. Prawo do milczenia ma uniemożliwić wykorzystanie informacji odnoszącej się do religii i wyznania przez jakiekolwiek osoby, w tym także

99 M. Pietrzak, Polskie prawo wyznaniowe wobec standardów..., s. 22. Autor ten myli się stwierdzając, że ust. 2 art. 18 Międzynarodowego Paktu Praw Obywatelskich i Politycznych mówi, że nikt nie może być zmuszany do ujawnienia swojej religii lub przekonań. W treści art. 18 ust. 2 wspomnianych Międzynarodowych Paktów stwierdzono jednoznacznie ,nikt nie może podlegać przymusowi, który stanowiłby zamach na jego wolność posiadania lub przyjmowania wyznania albo przekonań według własnego wyboru". Nie sposób uznać, iż treść tego przypisu statuuje wprost wolność milczenia w sprawach sumienia, wyznania, religii. Zapis, z którego wynika, że nikt nie może podlegać przymusowi, który stanowiłby zamach na jego wolność posiadania lub przyjmowania wyznania albo przekonań według własnego wyboru nie jest jednoznaczny ze stwierdzeniem, że nikt nie może być zmuszany do ujawnienia swojej religii lub przekonań. Przyznać jednak należy, iż prawo do zachowania $\mathrm{w}$ tych kwestiach milczenia można wyprowadzić z treści art. 18 ust. 2 wspomnianych Międzynarodowych Paktów.

100 Jako wysoce dyskusyjne jawi się ujawnienie na świadectwie maturalnym oceny $\mathrm{z}$ religii. Wprawdzie uczestnictwo w zajęciach religii nie ma charakter obowiązkowego, ale brak oceny z religii oznacza nieuczestniczenie w takowych zajęciach, co wskazuje na światopogląd osoby legitymującej się takim świadectwem. 
przez funkcjonariuszy władzy publicznej, do uprzywilejowania kogokolwiek lub dyskryminowania. Prawo do milczenia w sprawach religii lub przekonań statuuje art. 2 pkt 5 ustawy z dnia 17 maja 1989 r., gwarantujący wolność sumienia i wyznania (t.j. Dz. U. 2005, Nr 231, poz. 1968).

$\mathbf{Z}$ wolności zmiany przekonań, wyznania (religii) wynika prawo do podejmowania prób przekonania do swojej wiary innych ludzi np.: przez nauczanie. Jak zauważył Europejski Trybunał Praw Człowieka w Strasburgu ,z wolności religii wynika również prawo do podejmowania prób przekonania do swojej wiary sąsiada i innych ludzi np.: przez nauczanie”. Bez tego „wolność zmiany religii lub przekonań”, o której mowa w art. 9 Europejskiej Konwencji o Ochronie Praw Człowieka i Podstawowych Wolności pozostałoby martwą literą ${ }^{101}$. Wolność nauczania jako formę uzewnętrzniania swojego wyznania statuuje Europejska Konwencja o Ochronie Praw Człowieka i Podstawowych Wolności w art. 9 ust. 1, Międzynarodowy Pakt Praw Obywatelskich i Politycznych w art. 18 ust. 1 oraz Powszechna Deklaracja Praw Człowieka w art. $18^{102}$. W Konstytucji w art. 53 ust. 2 mowa jest o wolności uzew-

101 Kokkinakis przeciwko Grecji - orzeczenie z 25 maja 1993 r., A. 20-A; raport Europejskiej Komisji Praw Człowieka z 3 grudnia 1991 r., skarga nr 14307/88; zob. Europejski Trybunat Praw Człowieka, orzecznictwo, t. 2: Prawo do życia i inne prawa, oprac. M. A. Nowicki, Zakamycze 2002, s. 926-929. Teza wspomnianego orzecznictwa była potem wielokrotnie powtarzana przy okazji rozstrzygania innych spraw. Warto zauważyć, że Europejski Trybunał we wspomnianej sprawie wyraziście odróżnił „,prawdziwą ewangelizację” (true evangelism) od „niestosownego prozelityzmu” (improper proselytism), stwierdzając że ,ten drugi stanowi jej wypaczenie czy deformację”, przyjmując formę „działalności oferującej materialne czy socjalne korzyści celem pozyskiwania kościołowi nowych członków" bądź wywierania niestosownej presji na ludzi pogrążonych w strapieniu lub w potrzebie. Może nawet zawierać w sobie użycie przemocy bądź pranie mózgów (brainwashing). Jest rzeczą znamienna, że Trybunał nie uznał sformułowania, iż tego typu praktyki są sprzeczne z wolnością religii, lecz zauważył, iż nie dają się one pogodzić z poszanowaniem wolności myśli sumienia i religii innych osób.

102 Podkreślić należy, że Powszechna Deklaracja Praw Człowieka wymienia nauczanie, jako formę uzewnętrznienia religii bądź przekonań na pierwszym miejscu w katalogu zakresu przedmiotowego wolności myśli, sumienia i wyznania. Natomiast Międzynarodowy Pakt Praw Obywatelskich i Politycznych wskazuje nauczanie w takim katalogu form manifestowania przekonań na miejscu ostatnim - po uprawianiu kultu, uczestnictwa w obrzędach, praktykowaniu. Z kolei Europejska Konwencja o Ochronie Praw Człowieka i Podstawowych Wolności wymienia nauczanie po uprawianiu kultu, ale przed praktykowaniem i czynnościami rytualnymi. Rozwiązanie przyjęte w treści art. 53 ust. 2 zdanie pierwsze najbardziej zbliżone jest 
nętrznienia religii przez nauczanie. Pojęcie nauczania nie zostało zdefiniowane w treści Konstytucji. Niewątpliwie jednak nie chodzi tu o nauczanie w sensie edukacji szkolnej. Pod pojęciem nauczania w rozumieniu art. 53 ust. 3 należy rozumieć głoszenie doktryny religijnej. Wolność nauczania, jak przyjmuje się w literaturze, może być realizowana $\mathrm{w}$ dwóch płaszczyznach: wewnętrznej (ad intra) i zewnętrznej (ad extra). Nauczanie w zakresie wewnętrznym skierowane jest do członków wspólnoty religijnej - czyli do osób, które utożsamiają się z określonymi przekonaniami religijnymi. Chodzi w tym przypadku o pogłębianie i rozwój wiary oraz posiadanych przekonań w łonie określonej denominacji religijnej ${ }^{103}$. Kwestią tą prawo konstytucyjne bliżej się nie zajmuje. Konstytucja podobnie jak Powszechna Deklaracja Praw Człowieka i Podstawowych Wolności nie precyzuje ani form, ani trybu tego nauczania ${ }^{104}$.

Nauczanie w zakresie zewnętrznym obejmuje propagowanie wiary, skierowane do zwolenników innych wyznań oraz ateistów. Pod pojęciem nauczania - w aspekcie zewnętrznym, w rozumieniu art. 53 ust. 2 zdanie pierwsze Konstytucji oraz art. 9 ust. 1 Europejskiej Konwencji o Ochronie Praw Człowieka i Podstawowych Wolności wypada rozumieć także głoszenie przekonań religijnych ${ }^{105}$. Stanowisko takie podzielają także badacze stojący na gruncie katolickiej nauki społecznej ${ }^{106}$.

do przyjętego w art. 18 Międzynarodowego Paktu Praw Obywatelskich i Politycznych, gdyż też wymienia w odpowiednim katalogu nauczanie na ostatnim miejscu po uprawianiu kultu, modlitwie, uczestniczeniu w obrzędach, praktykowaniu. Trudno dociec zarówno przyczyn rozbieżności w budowie katalogu we wspomnianych trzech aktach normatywnych, jak i przyczyn, dla których w Polsce przyjęto rozwiązanie najbliższe Międzynarodowemu Paktowi Praw Obywatelskich i Politycznych, a stosunkowo dalekie tekstowi Europejskiej Konwencji o Ochronie Praw Człowieka i Podstawowych Wolności.

${ }^{103} \mathrm{~K}$. Warchałowski, Wolność uzewnętrznienia religii i przekonań religijnych w Europejskiej Konwencji Praw Człowieka, „Kwartalnik Prawa Publicznego” 2002, s. 197; D. J. Harris, M. O'Boyle, C. Warbrick, Law of the European Convention on Human Rights, London-Dublin-Edinburgh 1995, s. 365.

${ }^{104} \mathrm{Z}$ samej istoty wspomnianych aktów wynika, że nie mogą one zawierać przypisów określających szczegółowo formy wykonywania prawa, ponieważ zależą one od tradycji, uwarunkowań politycznych i społecznych poszczególnych państw, por. H. Suchocka, Nanczanie religii w ustawodawstwie europejskim, w: Nauczanie religii w szkole w państwie demokratycznym, red. J. Krukowski, Lublin 1991, s. 87.

105 J. A. Frowein, Article 9, w: La Convention Européene des Droits de l'Homle - Commentaire article par article, red. L. E. Pettiti, E. Decaux, P. H. Imbert, Paris 1998, s. 353-360.

${ }^{106}$ K. Warchałowski, Prawo do wolności myśli..., s. 115. 
Tak rozumiane prawo nauczania oznacza przekonanie do swoich poglądów oraz podejmowanie działalności misyjnej dla pozyskiwania nowych wyznawców. W literaturze wyraźnie podkreśla się, że jest rzeczą naturalną, iż człowiek, który głęboko w coś wierzy pragnie przekonać do tego innych. Każda religia, wszelkie wyznania mają z natury rzeczy ambicje maksymalistyczne. Dlatego też nie sposób zakreślić granic wierzeń i poglądów tylko jednego człowieka ${ }^{107}$. Innymi słowy propagowanie przez osoby fizyczne, kościoły oraz związki wyznaniowe, a także organizacje religijne doktryn religijnych, areligijnych i antyreligijnych jest oczywiście dopuszczalne. Winno to jednak odbywać się w sposób kulturalny bez poniżania innych przekonań oraz bez wykorzystywania silniejszej pozycji w międzyludzkich relacjach. Na płaszczyźnie międzynarodowej w orzecznictwie Europejskiego Trybunału Praw Człowieka stwierdza się wyraźnie, iż dopuszczalny jest prozelityzm, czyli dążenie do nawracania innych na swoją wiarę oraz chęć zdobycia jak największej liczby zwolenników dla danej idei czy światopoglądu ${ }^{108}$.

Z nauczaniem ściśle łączy się możliwość krytykowania innych wyznań, religii, bądź przekonań. Kwestii tej nie dotyka katalog obejmujący zakres przedmiotowy wolności sumienia i wyznania. Mieści się ona jednak w pojęciu nauczania, gdyż wszelkie nauczanie zasad religijnych może wiązać się i najczęściej wiąże się z krytyką. Krytykę taką, zgodnie z zakresem podmiotowym wolności religijnej mogą uprawiać osoby indywidualne, kościoły, związki wyznaniowe, grupy społeczne oraz stowarzyszenia. Od takowej krytyki musi się powstrzymać państwo, którego obowiązkiem jest zapewnienie wolności religijnej na równych prawach

107 W. Sadurski, Wartości chrześcijańskie. Trybunat i tolerancja, „Rzeczpospolita" nr 196, z 25 sierpnia 1994, s. 3.

108 Kokkinakis przeciwko Grecji - orzeczenie z 25 maja 1993 r. A.260-A; raport Europejskiej Komisji Praw Człowieka z 3 grudnia 1991, skarga nr 14307/88 w: Europejski Trybunat Praw Człowieka, t. 2, s. 926-929; Larissis, Mandalaridis i Sarandis przeciwko Grecji, 24.2.1998, RJD 1998-I, zob. M. A. Nowicki Europejska Konwencja Praw Człowieka. Wybór orzecznictwa, t. 2, Warszawa 1999, s. 389. Warto zauważyć, że w optyce Trybunału Praw Człowieka nauczanie, a co za tym idzie prozelityzm wymaga od nauczającego otwartości i uczciwości poszanowania wyznania i poglądów innych, a także unikanie przebiegłych, podstępnych i niewłaściwych środków bądź fałszywych podtekstów. Niedopuszczalny jest także prozelityzm polegający na oferowaniu socjalnych i materialnych korzyści pozyskiwanym zwolennikom, manipulowaniu ludźmi, którzy znaleźli się w trudnym położeniu, uciekaniu się do przemocy. 
wszystkim religiom i przekonaniom. Dlatego nie powinno wypowiadać się w sposób, który pozwalałby komukolwiek mniemać, że zabiera ono głos i zajmuje stanowisko w sporach religijnych bądź światopoglądowych. Niedopuszczalna jest więc indoktrynacja religijna, czy filozoficzna uprawiana przez państwo ${ }^{109}$.

W literaturze zauważa się, iż krytyka religii, wyznań lub przekonań może uderzać w krytykowanie wierzenia lub przekonania do tego stopnia, że wyznawcy danej religii lub zwolennicy określonych przekonań mogą się czuć nimi dotknięci, bądź głęboko poruszeni. Mimo wszystko krytyka powinna być rzeczowa, odwoływać się do rozumu, ogólnoludzkich wartości, zasad naturalnych. Członkowie społeczności religijnych muszą tolerować i akceptować negowanie ich przekonań religijnych, a nawet propagowanie zasad wrogich ich wierze ${ }^{110}$.

Wolność nauczania zawarta w art. 53 ust. 2 zdanie pierwsze Konstytucji ma dla mniejszości wyznaniowych charakter obosieczny. Z jednej strony bowiem pozwala tym mniejszościom na zabiegi prozelitorskie, a więc pozyskiwanie nowych wyznawców, z drugiej zaś strony zmusza je do godzenia się na krytykę i działania prozelitorskie podejmowane przez wyznawców innej religii, w tym też dominujący w Polsce Kościół katolicki. Zważywszy na siłę tego Kościoła jego możliwości propagandowe moga być to działania niebezpieczne dla istnienia takich mniejszości, w szczególności tych, które mogą być zaliczane do „,nowych ruchów religijnych" (tzw. sekty). Siła oddziaływania dominującego Kościoła katolickiego może być także niebezpieczna dla ateistów i agnostyków, ale i oni zgodnie z międzynarodowymi standardami art. 53 ust. 2 zdanie pierwsze Konstytucji muszą akceptować wolność nauczania, jaką cieszą się wyznawcy wszystkich religii.

Praktykowanie stanowi kolejną formę uzewnętrzniania wyznania (religii) lub przekonań. Konstytucja w art. 53 ust. 2 zdanie 1 oddziela prak-

109 Kościół Scjentologiczny i 128 wyznawców przeciwko Szwecji. Skarga nr 828/78 - Decyzje z 14 lipca 1980, DR21, s. 109 i n., s. 110-111; zob. Wolność religii. Wybór materiałów. Dokumenty. Orzecznictwo, tłum. i oprac. T. Jasudowicz, Toruń 2001, s. 217 i n.; por także G. Gonzalez, La Convention Européenne des droits de l'Homle et la liberté des religions, Paris 1997, s. 97.

110 Decyzja Trybunału w Strasburgu w sprawie Dubowska i Skup przeciwko Polska, 18 kwietnia 1979, skargi nr 34055/96 i 33490/96, DR 89-A/96, w: Europejski Trybunał Praw Człowieka, t. 2, s. 920; zob. także M. Granat, Granice wolności religijnej w społeczeństwie pluralistycznym, w: Kultura i Prawo, t. 3: Religia i wolność religijna w Unii Europejskiej, red. J. Krukowski, O. Theisen, Lublin 2003, s. 182 i n. 
tykowanie od uprawiania kultu, modlitwy, uczestnictwa w obrzędach ${ }^{111}$. Podobnie widzi tę sprawę art. 9 Europejskiej Konwencji o Ochronie Praw Człowieka i Podstawowych Wolności oraz art. 18 Międzynarodowego Paktu Praw Człowieka i Politycznych. Literatura, zwłaszcza związana z katolicką nauką społeczną, wyraźnie skłania się do tego, iż praktykowanie to uprawianie kultu, modlitwa i uczestniczenie w obrzędach ${ }^{112}$. Niewątpliwie zakres tej formy manifestowania religii jest najszerszy i w tym rozumieniu jest to każde postępowanie motywowane religijnie. W węższym zakresie praktykowanie ogranicza się do aktów należących ściśle do kultu religijnego takich jak: modlitwa, uczestniczenie w obrzędach. Trudno ustalić, co legło u podstaw koncepcji ustawodawcy poza oczywistą konstatacją, iż ustawodawca chciał odnieść się do treści zawartych w Powszechnej Deklaracji Praw Obywatelskich i Politycznych oraz Europejskiej Konwencji Praw Człowieka i Podstawowych Wolno-

111 W kwestii przejawów uzewnętrzniania religii zob. J. Krukowski, Konstytucyjna ochrona wolności sumienia i religii, w: Sześć lat Konstytucji Rzeczypospolitej Polski. Doświadczenia i inspiracje, Warszawa 2003, s. 163. W prawie międzynarodowym zwraca się uwagę, że państwo powinno powstrzymywać się od ingerencji w sferę obrzędów i modlitwy, zob. M. Rozner, Prawo do wolności religijnej w Europejskiej Konwencji Praw Człowieka z 1950 r., „Studia z Prawa Wyznaniowego” 2002, t. 5, s. 122.

112 K. Krukowski, Prawo do wolności myśli, s. 121. Warto zauważyć, że terminem „kult” posługuje się także Konkordat między Stolicą Apostolską a Rzeczpospolitą Polską podpisany w Warszawie dnia 28 lipca 1993 r. (Dz. U. 1998, Nr 51, poz. 319). W art. 8 ust. 1 Konkordatu stwierdzono, że „Rzeczpospolita Polska zapewnia Kościołowi katolickiemu sprawowanie kultu zgodnie z art. 5". W kolejnym ustępie zauważono, że „organizowanie kultu publicznego należy do władzy kościelnej zgodnie z przepisami prawa kanonicznego i zgodnie z przepisami prawa polskiego”. Jednocześnie zauważono, że „miejscom przeznaczonym przez właściwą władzę kościelną do sprawowania kultu i grzebania zmarłych Państwo gwarantuje w tym celu nienaruszalność" (art. 8 ust. 3 zd. pierwsze Konkordatu). W ustępie 4 tegoż artykułu stwierdzono: „sprawowanie kultu publicznego w miejscach innych niż określone w ustępie 3 nie wymaga zezwolenia władz państwowych..." [sic! przyp. mój W.S.]. Analiza wspomnianych przepisów prowadzi do wniosku, że przynajmniej z punktu widzenia Kościoła katolickiego należy odróżnić „kult” od „kultu publicznego". W Kodeksie Prawa Kanonicznego (Codex Iuris Canonici) wyróżnia się w księdze IV zatytułowanej „Uświęcające Zadanie Kościoła” część pierwszą poświęconą siedmiu sakramentom (Chrzest, Bierzmowanie, Najświętsza Eucharystia, Sakrament Pokuty, Sakrament Namaszczenia Chorych, Święcenia, Małżeństwo) oraz część drugą zatytułowaną „Pozostałe Akty Kultu Bożego” wśród których wskazano: sakramentalia, liturgię godzin, pogrzeb kościelny, kult świętych, obraz, relikwi, ślub i przysięgę. 
ści. Warto jednak zauważyć, iż wszystkie trzy wspomniane akty prawa międzynarodowego w podobny sposób, niekonsekwentnie zdają się nie zauważać, że praktykowanie to nic innego jak uprawianie kultu, a także uczestniczenie w obrzędach. Podkreślić należy przy tym, że żaden ze wspomnianych trzech aktów prawa międzynarodowego nie wskazuje modlitwy jako jednego z elementów katalogu mieszczącego w sobie zakres przedmiotowy wolności wyznania. Zważyć przy tym należy, iż uprawianie kultu wskazuje w zakresie przedmiotowym obok praktykowania nie tylko art. 53 ust. 2 Konstytucji, ale także każdy ze wspomnianych trzech aktów normatywnych. Zważywszy jednak na założenie o racjonalności prawodawcy oraz na to, że zasady wykładni nie pozwalają na przyjęcie tezy, iż jakiekolwiek terminy użyte w tekście przepisu mogą być uznane za zbędne lub powtarzające się ${ }^{113}$, konstatacja ta nakazywała zbadanie, jaki jest stosunek zakresu pojęciowego terminów; „uprawianie kultu” i „praktykowanie”. Wykładnia językowa prowadzi do wniosku, że „praktykowanie” to wykonywanie praktyk religijnych ${ }^{114}$. Pod pojęciem praktyk religijnych zwykło się rozumieć udział w nabożeństwach, obrzędach religijnych, w religii katolickiej przystępowanie do spowiedzi, komunii, modlenie się, w islamie wypełnianie pięciu filarów islamu ${ }^{115}$. Dokonując wykładni wyrażenia uprawianie kultu należy stwierdzić, iż uprawiać to zajmować się czymś, oddawać się czemuś, poświęcać się czemuś ${ }^{116}$. Pod pojęciem kultu należy rozumieć „zewnętrzny aspekt religii w odróżnieniu od teoretycznej doktryny, ogół obrzędów religijnych jakiejś religii, całokształt czynności religijnych" ${ }^{\prime 17}$. Termin „kult” pochodzi od łacińskiego słowa „cultus” oznaczającego

113 S. Wronkowska, Podstawowe pojęcia prawa i prawoznawstwa, wyd. II, Poznań 2003, s. 82; M. Zieliński, Wykładnia prawa. Zasady reguły, wskazówki, Warszawa 2002 , s. 288 i n.

114 Stownik języka polskiego, red. M. Szymczak, t. 2, Warszawa 1988, s. 908; Uniwersalny słownik języka polskiego, red. S. Dubisz, t. 3, Warszawa 2003, s. 533.

115 Są nimi szahada - wyznawanie wiary, salat - modlitwa, zakat - jałmużna, saum - post, hadżdż - pielgrzymka do Mekki. Wbrew powszechnemu przekonaniu dżihad - wojna święta nie należy do filarów islamu i nie może być pojmowany jedynie jako rozpowszechnianie islamu drogą oręża; zob. J. Danecki, Podstawowe wiadomości o islamie, t. 1, Warszawa 2002, s. 129 i n.

116 Słownik języka polskiego..., t. 3, s. 610, Uniwersalny słownik języka polskiego..., t. 4, s. 262.

117 Słownik języka polskiego..., t. 1, s. 1083, Uniwersalny słownik języka polskiego..., t. 2, s. 357 . 
wychowanie, pielęgnowanie, wykształcenie, ćwiczenie, a wreszcie hołd i uwielbienie. Pod terminem tym zwykło się rozumieć postawę czci i uwielbienia wobec sakrum, a także całokształt praktyki i zachowań taką postawę wyrażających. Mogą to być zachowania polegające na działaniu (pielgrzymka, procesja, ofiara, rytualne obmycie, zdjęcie nakrycia głowy lub jego nałożenie, zdjęcie obuwia). Może także kult polegać na powstrzymywaniu się z pobudek religijnych od pewnego postępowania np.: post, abstynencja seksualna. Kult może przybierać formę werbalną, objawiać się w głośnej modlitwie, śpiewie religijnym, homiliach i kazaniach, ewentualnie wewnętrzną, nie zawsze dostrzeganą przez obserwatorów (medytacje, kontemplacje). Kult może być spełniany zbiorowo - wówczas ma charakter publiczny lub indywidualnie i wtedy przyjmuje postać kultu prywatnego ${ }^{118}$. Kult publiczny może pozostawać pod kontrolą państwa, tak jak to miało miejsce w starożytnym Rzymie. Może także być sprawowany przez zamknięte grupy, bractwa o charakterze religijnym $^{119}$. Rozróżnia się formy apotropeiczne (ochronne) kultu, eliminujące zło ze wspólnoty (oczyszczające) oraz formy kultu jednoczące wspólnotę ${ }^{120}$. Tak więc wykładnia językowa musi prowadzić do wniosku, że „praktykowanie” to nic innego jak „uprawianie kultu”.

118 W. Bar, Wolność kultu religijnego, w: Prawo wyznaniowe, red. H. Misztal, P. Stanisz, wyd. II, Lublin 2003, s. 266.

119 M. Eliade, Historia wierzeń i idei religijnych, t. II, Warszawa 1994, s. 82-84.

120 E. Ciupak, Kult religijny i jego społeczne podłoże, Warszawa 1965, s. 27 i n. W religioznawstwie wyróżnia się wiele odmian kultów: agrarne, astralne, lunearne, solarne, bóstw, duchów, gór, herosów przodków, roślin, świętych, relikwii, obrazów, wegetacyjne, władców, zmarłych, zwierząt. W judaizmie odróżnia się kult świątynny od synagogalnej służby bożej. W hinduizmie kult ewoluuje od wedyjskiej zasady ofiary (jadźń) poprzez kult jako sposób zachowania czystości rytualnej aż do kultu jako adoracji (pudźa) i osobistej pobożności (bhakti), czyli oddania się bóstwu. W Chinach kult miał zapewnić niezakłócone funkcjonowanie natury i społeczeństwa przez zachowanie równowagi między niebem a ziemią. Wykonawcą kultu był cesarz. W islamie kult jest nieodłączny z życiem wiernego, z których każdy podporządkowuje się woli Boga. W katolicyzmie od czasów św. Tomasza z Akwinu odróżnia się kult obejmujący także akty nieliturgiczne od liturgii czyli służby bożej. W tym stanie rzeczy kult staje się wyrazem ludzkiej adoracji Boga, podczas gdy liturgia jest zarazem adoracją Boga, jak i zbawczym działaniem wobec ludzi, w sakramentach za pośrednictwem Chrystusa. Warto pamiętać, że kult w toku rozwoju religii ulega zmianom (np. Św. Augustyn długi czas występował przeciwko kultowi męczenników, piętnując handel relikwiami, zmienił zdanie około $425 \mathrm{r}$. dając temu wyraz w księdze 22 „De civtate dei”). W literaturze podkreśla się że kult relikwii miał charakter ludowy, ale zbliżał w żarliwości ludzi do boga; zob. M. Eliade, Histo- 
Próbę zdefiniowania wyrażenia ,praktykowanie” podjęto na gruncie Europejskiej Konwencji o Ochronie Praw Człowieka i Podstawowych Wolności, aczkolwiek czyniono to w sposób kazuistyczny w odniesieniu do konkretnych przypadków. Zdaniem Komisji, rozpatrującej skargi na łamanie konwencji jeszcze przed powstaniem Trybunału Praw Człowieka w Strasburgu ,praktykowaniem” nie jest rozdawanie ulotek pacyfistycznych, pikietowanie klinik dokonujących aborcji, odmowa obowiązkowych szczepień, złożenie fotografii potrzebnej do wydania dyplomu zakrywającej twarz ubiegającej się o jego wydanie kobiety, chęć rozrzucenia prochów na działce ${ }^{121}$. Tylko w jednej z decyzji Komisji podjęto próbę ogólnego określenia terminu ,praktykować” wskazując, że nie dotyczy on działań, które bezpośrednio nie wyrażają przekonań, nawet wtedy, gdy są nimi motywowane. Wskazano, że art. 9 Konwencji poprzez termin ,praktykowanie" chroni także czynności, jak kult i modlitwa, które są wyrazem praktykowania religii czy przekonań w ogólnie przyjętej formie ${ }^{122}$. Za-

ria wierzeń i idei religijnych, t. III, s. 38-40. Socjologowie religii podkreślają że modlitwa, ofiara i rytuał nie tylko wyrażają doświadczenia uczestników, lecz przyczyniają się w niemałym stopniu, do kształtowania i określania organizacji ducha grupy. W chrześcijaństwie wyróżniają oni trzy typy zjednoczenia we wspólnym kulcie: zbiorowe milczenia, akty kultowe wykonywane $\mathrm{w}$ imieniu zgromadzenia przez przywódcę bądź jego pomocników oraz akty obrzędowe, czyli liturgiczne, w których uczestniczą wszyscy. Wraz z rozwojem bardziej skomplikowanego systemu praktyk kultowych rośnie potrzeba znawców oraz pojawia się zjawisko zastrzegania pewnych aktów kultu dla pewnego zespołu osób, które monopolizują pewne czynności kultowe. Zauważa się, że ważnym fazom w życiu jednostki (narodziny, osiagnięcie dojrzałości, małżeństwo, śmierć) towarzyszą określone działania kultowe. Kult integruje społeczeństwo, co ujawnia się w tworzeniu przejściowych lub trwałych form organizacyjnych; zob. J. Wach, Socjologia religii, Warszawa 1961, s 65-70; B. Malinowski wyraźnie podkreśla, że każdy moment przełomowy w życiu człowieka wywołuje zbiorowe zainteresowanie społeczności i obrasta w elementy kultowe zważając, że uroczysty i publiczny charakter ceremonii kultowych jest wyróżniająca cechą religii w ogóle, gdyż religia potrzebuje społeczności jako całości, a społeczność potrzebuje religii, aby utrzymać prawo moralne i porządek. (B. Malinowski, Mit, nauka i religia, w: tegoż, Dzieła, t. VII: Mit, magia, religia, s. 408 i 420).

${ }^{121}$ Analizę decyzji Komisji odmawiających określonym działaniom przymiotu „praktykowania” dokonuje K. Warchałowski, Prawo do wolności myśli, s. 121-130; zob. także M. Pernal, Gwarancje wolności religijnej w Europejskiej Konwencji o Ochronie Praw Człowieka (w świetle orzecznictwa Komisji o Ochronie Praw Człowieka), „Państwo i Prawo” 1992, z. 11, s. 80.

122 V. przeciwko Holandii decyzja z 5 lipca 1984 r., skarga nr 10678/83, zob. Wolność religii. Wybór materiałów. Dokumenty, orzecznictwo, thum. i oprac. T. Jasudowicz, s. 243. 
uważono, że przedmiotem ochrony jest sfera przekonań osobistych i wyznania religijnego tj. obszar, który bywa czasem nazywany forum internum. Podkreślono także, że praktykowanie religii lub przekonań obejmuje działania, które są bezpośrednio i ściśle z nimi związane, będąc elementami praktyki religijnej w powszechnie uznanej formie (sprawowanie kultu, modlitwa). Tak więc nie każde postępowanie motywowane religijnie jest praktykowaniem w rozumieniu art. 9 Europejskiej Konwencji ${ }^{123}$.

W tym miejscu podzielić należy dokonaną wykładnię terminu ,,praktykowanie" uznając, że ma ona zastosowanie także do znaczenia tego terminu w Konstytucji. Konstatacja ta nie rozwiązuje jednak problemu synonimiczności określeń „praktykowanie” oraz „uprawianie kultu”, a jedynie synonimiczność tę potwierdza. Wykładnia celowościowa także nie rozwiązuje problemu, gdyż nie sposób dociec powodów, dla których wspomniane akty prawa międzynarodowego oraz Konstytucja sięgają do, w istocie synonimicznych, określeń. Odpowiedź na to frapujące pytanie nie udziela także wykładnia historyczna.

Zgodzić się należy ze stanowiskiem doktryny co do tego, że elementem praktykowania religii nie jest małżeństwo jako instytucja religijna. Stanowi ono jednak wyraz uzewnętrzniania religii nie chroniony przez dyspozycję art. $9^{124}$.

Ogólnikowy charakter stwierdzeń zawartych w art. 53 ust. 2 zd. 1 Konstytucji oraz we wspominanych trzech aktach prawa międzynarodowego (Konwencji, Międzynarodowego Paktu i Powszechnej Deklaracji) uszczegółowia nieco na gruncie krajowym art. 2 ustawy z dnia 17 maja

$123 \mathrm{~K}$. Warchałowski, Wolność uzewnętrzniania religii i przekonań religijnych w Europejskiej Konwencji Praw Człowieka, „Kwartalnik Prawa Publicznego” 2002, nr 1-2, s. 208.

124 Stanowisko takie prezentuje K. Warchałowski, aprobując poglądy zawarte w uzasadnieniu decyzji Komisji w sprawie Janis Khan przeciwko Zjednoczonemu Królestwu, skarga nr 11579/85 - decyzja z 7 lipca 1986 r.; zob. K. Warchałowski, Prawo do wolności myśli..., s. 132-134. Tekst uzasadnienia decyzji Komisji, Wolność religii..., tłum. i opr. T. Jasudowicz, s. 251-252. Nie sposób jednak zaprzeczyć, iż fakt że w oparciu o ustalenia Konkordatu między Stolicą Apostolską a Rzeczpospolitą Polską „małżeństwo kanoniczne”, a więc zawarte zgodnie z przepisami Kodeksu Prawa Kanonicznego Kościoła Rzymskokatolickiego oraz tych wyznań, których status określany jest stosownymi ustawami regulującymi stosunek Rzeczypospolitej do nich, wywiera takie skutki, jakie pociaga za sobą zawarcie małżeństwa zgodnie z prawem cywilnym - to nie można wątpić, iż jest to rozwiązanie wyróżniające i uprzywilejowujące z jednej strony wyznawców tych religii, z drugiej zaś duchownych tych wyznań. 
1989 r. o gwarancjach wolności sumienia i wyznania ${ }^{125}$. W myśl treści art. 2 tejże ustawy korzystający z wolności sumienia i wyznania może uczestniczyć w czynnościach i obrzędach religijnych oraz wypełniać obowiązki religijne i obchodzić święta religijne, głosić swoją religię lub przekonania, wychowywać dzieci zgodnie ze swoimi przekonaniami w sprawach religii, zachowywać kontakty ze swoimi współwyznawcami, w tym także uczestniczyć w pracach organizacji religijnych o zasięgu międzynarodowym, korzystać ze źródeł informacji na temat religii, wytwarzać i nabywać przedmioty do celów kultu i praktyk religijnych oraz korzystać z nich, wytwarzać, nabywać i posiadać artykuły potrzebne do przestrzegania reguł religijnych, wybrać stan duchowny lub zakonny, zrzeszać się $\mathrm{w}$ organizacjach $\mathrm{w}$ celu realizacji zadań wynikających w wyznawanej religii, bądź przekonań w sprawach religii, otrzymać pochówek zgodny z wyznawanymi zasadami religijnymi lub przekonaniami w sprawach religii.

$\mathrm{Na}$ gruncie prawa międzynarodowego doprecyzowuje katalog - obejmujący zakres przedmiotowy wolności sumienia i wyznania - art. 6 Deklaracji w Sprawie Wyeliminowania Wszelkich Form Nietolerancji i Dyskryminacji Opartych na Religii lub Przekonaniach z 25 listopada 1981 r. $^{126}$

Pamiętać należy jednak, iż Deklaracja w Sprawie Wyeliminowania Wszelkich Form Nietolerancji i Dyskryminacji Opartych na Religii lub Przekonaniach nie ma charakteru prawnego, a jest dokumentem o znaczeniu politycznym i moralnym. Jest przy tym rzeczą jasną, że zarówno wskazania zawarte we wspomnianej Deklaracji, jak i treść przywołanej ustawy z dnia 17 maja 1989 r. o Gwarancjach Wolności Sumienia i Wyz-

125 T.j. Dz. U. 2005, Nr 231, poz. 1965.

126 Tekst Deklaracji zob. Wolność religii..., tłum. i opr. T. Jasudowicz, s. 77. W treści Deklaracji stwierdzono m.in. że: „Każdy ma prawo do wolności myśli, sumienia i religii. Prawo to obejmuje wolność wyznawania religii bądź jakichkolwiek przekonań według własnego wyboru, jak również wolność manifestowania swojej religii, lub przekonań - indywidualnie lub wespół z innymi, publicznie lub prywatnie - w modlitwie, obrzędach, praktykach i nauczaniu” (art. 1 ust. 1). W dalszej części stwierdzono „Nikt nie będzie podlegać przymusowi, który naruszałby jego wolność wyznawania religii lub przekonań według własnego wyboru.” (art. 1 ust. 2), „Wolność manifestowania swojej religii lub przekonań może podlegać jedynie takim ograniczeniom, które są przewidziane przez prawo i konieczne w demokratycznym społeczeństwie dla ochrony bezpieczeństwa, porządku, zdrowia lub moralności publicznej albo podstawowych praw i wolności innych osób” (art. 1 ust. 3). 
nania nie tworzy katalogu konstytucyjnego z zakresu przedmiotowego wolności sumienia i religii (wyznania), lecz jedynie służyć może jako pomocnicze źródło dla wykładni norm konstytucyjnych. Nie wolno przy tym zapominać, że Deklaracja w Sprawie Wyeliminowania Wszelkich Form Nietolerancji i Dyskryminacji Opartych na Religii lub Przekonaniach, jak i ustawa z 17 maja 1989 r. poprzedzają uchwalenie Konstytucji. Tym też należy tłumaczyć, że w ustawie z 17 maja 1989 r. o Gwarancjach Wolności Sumienia i Wyznania zarówno w tytule ustawy, jak i w tytule działu pierwszego, a także m.in. w art. 1 i art. 2 mowa o „wolności sumienia i wyznania”, podczas gdy Konstytucja posiłkuje się terminem „wolność sumienia i religii”. Przypomnieć wypada, że w myśl art. 1 ust. 1 pkt 2 wolność sumienia i wyznania obejmuje swobodę wyboru religii lub przekonań.

W zakresie przedmiotowym art. 53 ust. 1 zd. 1 Konstytucji nie wspomina o tym, iż statuowana tam wolność obejmuje czynności rytualne. O czynnościach rytualnych nie ma mowy także zarówno w Powszechnej Deklaracji Praw Człowieka, jak i w Międzynarodowym Pakcie Praw Obywatelskich i Politycznych. Jedynie Europejska Konwencja o Ochronie Praw Człowieka i Podstawowych Wolności wskazuje czynności rytualne jako jedną $\mathrm{z}$ form uzewnętrzniania indywidualnie lub wspólnie z innymi, publicznie lub prywatnie swego wyznania lub przekonań. W języku polskim ,rytuał to zespół czynności stanowiących ustaloną formę zewnętrzną społecznie doniosłego aktu, uroczystości, ceremonii”. W znaczeniu religioznawczym ,jest to ustalona forma praktyk religijnych" ${ }^{27}$. W tym stanie rzeczy ,rytuał” jawi się jako termin synonimiczny ,praktykowania”, aczkolwiek Europejska Konwencja ,praktykowanie” wymienia obok czynności rytualnych. Europejski Trybunał Praw Człowieka w Strasburgu wskazał, że do czynności rytualnych należy ubój rytualny ${ }^{128}$.

W katalogu zakresu przedmiotowego wolności sumienia i religii (wyznania) przewidzianego w art. 53 Konstytucji mieści się także prawo posiadania świątyń i innych miejsc kultu, prawo do korzystania z pomo-

127 Stownik języka polskiego, red. M. Szymczak, t. 3, s. 155; Uniwersalny słownik języka polskiego, red. S. Dubisz, t. III, s. 1107.

128 Jewish Litugical Association (Żydowskie Zjednoczenie Liturgiczne) Cha`are Shalon ve Tsedek przeciwko Francji - orzeczenie z 27 czerwca 2000 r., Wielka Izba, raport Europejskiej Komisji Praw Człowieka z 20 października 1998 r., skarga nr 274117/95, w: Nowy Europejski Trybunat Praw Człowieka, wybór orzeczeń 1999-2004, opr. A. Nowicki, s. 932-936. 
cy religijnej oraz możliwość, aby religia kościoła lub innego związku wyznaniowego, o uregulowanej sytuacji prawnej, była przedmiotem nauczania w szkole. Przy tej okazji ustrojodawca wskazuje, że nauczanie takie nie może naruszać wolności sumienia i religii innych osób. Wśród praw przedmiotowych wymienia się także prawo rodziców do zapewnienia dzieciom wychowania i nauczania moralnego i religijnego zgodnie $\mathrm{z}$ ich przekonaniami. Takie ujęcie jest jednak niewątpliwie błędne, gdyż prawo to ma charakter podmiotowy i w związku z tym zostało omówione wyżej, w podrozdziale poświęconym zakresowi podmiotowemu wolności sumienia i wyznania.

Nie da się zaprzeczyć, że koniecznym elementem zapewniającym swobodę uzewnętrznienia religii są obiekty i miejsca, w których kult może być sprawowany. Obiektami takimi mogą być budynki, a więc kościoły, kaplice i domy modlitwy, ale także otwarte przestrzenie, na których zbierają się wierni. Oczywiście przy powstaniu takich budynków muszą być spełnione wymogi prawa budowlanego oraz prawa o zagospodarowaniu przestrzennym. Wyznawcy jakiejkolwiek religii nie moga przy tym w sposób zasadny domagać się przeznaczenia na ich potrzeby jakiegokolwiek obiektu użytkowanego przez osoby prywatne bądź organizacje, stowarzyszenie, kościoły bądź związki wyznaniowe, a także urzędy, szkoły, szpitale. Nie da się przy tym wykluczyć sporów między poszczególnymi kościołami a związkami wyznaniowymi co do własności poszczególnych obiektów oraz roszczeń z tym związanych. Roszczenia takie są i mogą być kierowane pod adresem nie tylko innych denominacji religijnych, lecz także organów władzy publicznej. W praktyce polskiej obiektem takowych żądań są głównie budynki przeznaczone obecnie na cele użyteczności publicznej: szpitale, szkoły, domy opieki, urzędy ${ }^{129}$.

129 Do najgłośniejszych sporów w Polsce należy spór dotyczący klasztoru w Supraślu między Kościołem Katolickim a Polskim Autokefalicznym Kościołem Prawosławnym; spór o świątynie w Przemyślu między tymi kościołami. Zjawiskiem charakterystycznym jest to, że występujące $\mathrm{z}$ roszczeniami w odniesieniu do obiektów kultu religijnego, które w okresie od 1944-1989 zostały przyjęte przez władze publiczne na rozmaite cele, kościelne osoby prawne, zwłaszcza Kościoła katolickiego formułują z roszczenia w stosunku do obiektów, które należały ongiś do tego kościoła, ale zostały przejęte w różny sposób i w różnym czasie przed zmianą systemu politycznego w Polsce tj. przed 1944 r. Do najbardziej bulwersujących działań tego typu należy zgłoszenie przez osoby prawne Kościoła Katolickiego roszczenia do terenów zajętych obecnie przez Uniwersytet Warszawski, z których Kościół ten został wywłaszczony przez zaborcę rosyjskiego oraz roszczenie o zwrot budynków 
Jest rzeczą dyskusyjną, czy do miejsc sprawowania kultu można zaliczyć cmentarze, aczkolwiek nie ulega wątpliwości, że problem pochówku na cmentarzu wyznaniowym może mieć i ma istotne znaczenie dla wiernych wszelkich wyznań. Przypomnieć należy, że zgodnie z art. 2 pakt. 12 ustawy z dnia 17 maja 1989 r. o gwarancjach wolności sumienia i wyznania jednostka korzystając z wolności sumienia i wyznania ma prawo do pochówku zgodnego z wyznawanymi zasadami religijnymi lub przekonaniami religijnymi.

Kwestie związane z zakładaniem, rozszerzaniem, utrzymywaniem, zasadami pochówku reguluje ustawa z dnia 31 stycznia 1959 r. o cmentarzach i chowaniu zmarłych ${ }^{130}$.

byłego klasztoru dominikańskiego w Gdańsku opuszczonych przez ten zakon jeszcze w czasach reformacji. Warto w tym miejscu zauważyć, iż art. 61 ustawy z dnia 17 maja 1909 r. o stosunku Państwa do Kościoła Katolickiego w Rzeczypospolitej Polskiej przewiduje możliwość wszczęcia postępowania na wniosek kościelnych osób prawnych w przedmiocie przywrócenia im własności upaństwowionych nieruchomości przejętych m.in. w toku wykonywania ustawy z dnia 20 marca $1950 \mathrm{r}$. o przejęciu przez państwo dóbr martwej ręki, poręczeniu proboszczom posiadania gospodarstw rolnych i utworzeniu Funduszu Kościelnego (Dz. U. 1950, Nr 9, poz. 87 z późn. zm); na podstawie dekretu z 26 października 1945 r. o własności i użytkowaniu gruntów na obszarze m.st. Warszawy (Dz. U. 1950, Nr 50, poz. 279), w toku likwidacji zakonów bez habitowych i stowarzyszeń kościelnych na podstawie rozporządzenia Ministra Administracji Publicznej z 10 marca 1950 r. w sprawie przystosowania stowarzyszeń do przepisów prawa o stowarzyszeniach (Dz. U. 1950, $\mathrm{Nr}$ 9, poz. 98); wywłaszczonych, jeżeli odszkodowanie za wywłaszczoną nieruchomość nie zostało wypłacone lub podjęte, utracone przez kościół po 1948 r. w trybie egzekucji zaległości podatkowych. Problem, czy dyspozycją art. 61 ustawy z dnia 17 maja 1989 r. o stosunku Państwa do Kościoła Katolickiego w Rzeczypospolitej Polskiej objęte są także nieruchomości skonfiskowane przez rządy zaborcze, a po uzyskaniu niepodległości przejęte przez [państwo polskie stał się przedmiotem rozważań Trybunału Konstytucyjnego, który wskazał, że układ zawarty między Stolicą Apostolską a Rzeczpospolitą Polską z 20 czerwca 1938 r. rozstrzygał ostatecznie sprawę roszczeń Kościoła Katolickiego z tytułu własności ziem, których kościół został pozbawiony przez zaborcę rosyjskiego. Wskazał przy tym inne, wcześniejsze akty normatywne, które regulowały sprawy roszczeń majątkowych Kościoła z tytułu konfiskat dokonanych przez zaborcę rosyjskiego. W konkluzji uzasadnienia stwierdził, że art. 61 wspominanej ustawy nie może stanowić podstawy do przywrócenia kościelnym osobom prawnym ich praw do utraconych w przeszłości nieruchomości (uchwała Trybunału Konstytucyjnego z dnia 24 czerwca 1992 r. W.11/91; OTK 1992, nr 1, poz. 18).

130 T.j. Dz. U. 2000, Nr 23, poz. 295 z późn. zm. Problem funkcjonowania cmentarzy wyznaniowych uregulowano w stosownych ustawach określających stosunek 
Dyskusyjne wydaje się, czy w zakresie przedmiotowym katalogu wolności sumienia i religii (wyznania) mieści się prawo odmowy wykonania obowiązku nakazanego przez ustawę. W treści art. 53 Konstytucji nie sprecyzowano expressis verbis takiego prawa. Niemniej uznaje je Karta Podstawowych Praw Unii Europejskiej, będąca ciagle jeszcze dokumentem politycznym, w treści art. 10 ust. 2. Rozwiązanie to nie ma swojego odpowiednika w Europejskiej Konwencji o Ochronie Praw Człowieka i Podstawowych Wolności, jednak potwierdzały je uchwały organów Rady Europy i Unii Europejskiej oraz europejskie trybunały konstytucyjne ${ }^{131}$.

Wynikająca $\mathrm{z}$ art. 53 ust. 2 Konstytucji wolność wyznawania oraz uzewnętrzniania religii indywidualnie lub z innymi, publicznie lub prywatnie, zapewniona jest m.in. przez zagwarantowanie jako dni wolnych od pracy i nauki niedziel i dni świątecznych ${ }^{132}$. Korzystanie $\mathrm{z}$ dni wolnych

państwa do Kościoła Katolickiego (art. 45), Kościoła Adwentystów Dnia Siódmego (art. $10 \mathrm{i}$ art. 23), Polskiego Autokefalicznego Kościoła Prawosławnego (art. 33 $\mathrm{i}$ art. 35), Kościoła Chrześcijan Baptystów Rzeczypospolitej Polskiej (art. 10 i art. 28), Kościoła Ewangelicko-Augsburskiego Rzeczypospolitej Polskiej (art. 28), Ewangelicko-Metodystycznego Rzeczypospolitej Polskiej (art. 25), Kościoła Katolickiego Mariawitów Rzeczypospolitej Polskiej (art. 8 ust. 4), Kościoła Polskokatolickiego Rzeczypospolitej Polskiej (art. 19 i art. 22), Kościoła Starokatolickiego Mariawitów Rzeczypospolitej Polskiej (art. 198), Kościoła Zielonoświątkowego Rzeczypospolitej Polskiej (art. 22), Karaimskiego Związku Wyznaniowego Rzeczypospolitej Polskiej (art. 28 i art. 29), Muzułmańskiego Związku Religijnego Rzeczypospolitej Polskiej (art. 40), do gmin wyznaniowych żydowskich Rzeczypospolitej Polskiej (art. 23).

131 Zob. Constitutional Jurisprudence in the Area of Freedom of Religion and Beliefs, Warszawa 2000, s. 28 i n. Podkreśla się w literaturze, że prawo to znajduje zastosowanie przy odmowie służby wojskowej, wykonania niektórych zabiegów lekarskich, przy czym przesłanką odmowy mogą być przekonania religijne oraz wyznawane zasady moralne.

132 Konkordat między Stolicą Apostolską a Rzeczpospolitą Polską w art. 9 zamieszcza wykaz siedmiu dni świątecznych. Katalog ten pokrywa się z wykazem sformułowanym w art. 17 ust. 1 ustawy o stosunku państwa do Kościoła katolickiego. Strona kościelna stale podnosi, iż w katalogu tym brak jeszcze czterech dalszych tzw. świąt nakazowych. W świetle ustaw regulujących stosunek pomiędzy państwem a poszczególnymi kościołami i związkami wyznaniowymi przewidziano zwolnienie od pracy dla wyznawców Polskiego Autokefalicznego Kościoła Prawosławnego według kalendarza juliańskiego w dniu 7 stycznia (pierwszy dzień Bożego Narodzenia), 8 stycznia (drugi dzień Bożego Narodzenia) 19 stycznia (Chrzest Pański), 7 kwietnia (Zwiastowanie Najświętszej Maryi Panny) drugi dzień Wielkanocy, 19 sierpnia (Przemienienie Pańskie), 28 sierpnia (Zaśnięcie Najświętszej Maryi Panny). Dla osób należących do Kościoła Ewangelicko-Augsburskiego 
w polskim porządku prawnym narusza w sposób widoczny i jednoznaczny określoną w treści art. 25 ust. 1 Konstytucji zasadę równouprawnienia kościołów i innych związków wyznaniowych oraz wyrażoną w ust. 7 art. 53 Konstytucji zasadę, iż nikt nie może być obowiązany przez organy władzy publicznej do ujawnienia swojego wyznania. Okazuje się bowiem, że wierni Kościoła katolickiego korzystają z dni świątecznych bez zgłaszania takowej chęci komukolwiek, nie muszą też ich odpracowywać. Natomiast zwolnienie od pracy w dni świąteczne przewidziane ustawami dla wiernych innych wyznań uwarunkowane jest odpracowaniem czasu zwolnienia. Jeżeli odpracowanie to następuje w dni wolne od pracy lub w ramach godzin nadliczbowych pracownikowi nie przysługuje dodatkowe wynagrodzenie (art. 42 ust. 1, 2, 3 ustawy o gwarancjach wolności sumienia i wyznania). Warto zauważyć, że chcąc skorzystać ze zwolnienia od pracy pracownik nie należący do Kościoła katolickiego, a będący wiernym jednego z pozostałych kościołów lub związków wyznaniowych, powinien potrzebę zwolnienia zgłosić pracodawcy co najmniej 7 dni przed zwolnieniem, a pracodawca zawiadamia takiego

dniami wolnymi są: Wielki Piątek, Święto Wniebowstapienia Chrystusa Pana, oraz 31 października Święto Reformacji (art. 14). Osobom należącym do Kościoła Ewangelicko-Reformowanego przyznano prawo zwolnienia od pracy w Wielki Piątek oraz w Święto Wniebowstąpienia. W te same dni korzystać mogą ze zwolnień od pracy wierni Kościoła Ewangelicko-Metodystycznego i Kościoła Chrześcijan Baptystów, wyznawcy Kościoła Katolickiego Mariawitów mają prawo do zwolnienia od pracy 2 sierpnia (Święto Objawienia Wielkiego Miłosierdzia) i 23 sierpnia (Święto Krwi Przenajdroższej Pana Jezusa i Ofiary Mateczki), wiernym Kościoła Starokatolickiego Mariawitów przysługuje prawo do zwolnień jedynie w dniu 2 sierpnia (Dzień objawienia Wielkiego Miłosierdzia), wierni Kościoła Zielonoświątkowego mogą korzystać ze zwolnień od pracy w dniach Wielkiego Piątku, Wniebowstąpienia Pańskiego oraz drugiego dnia Pięciodziesiętnicy, dla wiernych Kościoła Adwentystów dnia Siódmego dniem świętym jest każda sobota i wierni tego kościoła mogą korzystać ze zwolnienia od pracy i nauki od zachodu słońca w piątek do zachodu słońca w sobotę. Osoby należące do gmin wyznaniowych żydowskich mają prawo do zwolnienia od pracy i nauki na czas szabasu trwającego od zachodu słońca w piątek do zachodu słońca w sobotę, ponadto z okazji Nowego Roku przysługują im dwa dni zwolnienia, z racji Dnia Pojednania jeden dzień, Święta Szałasów dwa dni, Zgromadzenia Ósmego Dnia jeden dzień, Święta Radości Tory jeden dzień, Święta Peasach cztery dni, Święta Szawnoty dwa dni. Terminy tych świąt określone są według kalendarza żydowskiego. Wierni Muzułmańskiego Związku Religijnego i Karaimskiego Związku Religijnego, których status określają ustawy z okresu II Rzeczypospolitej, mogą uzyskać zwolnienie od pracy na zasadach określonych w ustawie z dnia 17 maja 1989 r. o gwarancjach wolności sumienia i wyznania. 
pracownika o warunkach odpracowania nie później niż 3 dni przed dniem, zwolnienia ${ }^{133}$. Wymóg zgłaszania wniosków o udzielenie dni wolnych ujawnia przynależność religijną zainteresowanego stygmatyzując go w określony sposób, narażając go na przykrości, docinki, cierpkie uwagi, a nawet stawiając go w sytuacjach mało korzystnych w przypadku rozdziału nagród, awansów. Taki pracownik, którego pracodawcą lub zwierzchnikiem jest osoba związana $\mathrm{z}$ integrystycznymi środowiskami katolickimi, bądź hołdująca przesądom katolicyzmu ludowego może zasadnie liczyć się z groźbą zwolnienia z pracy. Dowodzi to, że szczytne w założeniach rozwiązanie konstytucyjne czy ustawowe spełniające, jeśli nie wszystkie, to większość standardów międzynarodowych okazują się w toku praktycznej realizacji mało istotnymi i fasadowymi. Szczególnie narażeni na tego typu przykrości bywają wierni gmin żydowskich oraz należący do muzułmańskiego i karaimskiego związku religijnego. Warto w tym miejscu dodać, iż w jeszcze gorszym położeniu znajdują się tzw. świadkowie Jehowy, których sytuacja nie została jak dotąd uregulowana na poziomie ustawy, chociaż stanowić oni mają w Polsce drugą po katolikach grupę wyznaniową.

\section{The problems related to religious schools being financed from public resources as opposed to the freedom of conscience and religion in the political system of Poland}

\section{Summary}

The issue of religious schools being financed from public resources in Poland needs to be approached primarily from the point of view of the constitutional guaranties of the freedom of conscience and religion. To this end the regulations of the Law of May 17, 1989 on the guarantees of the freedom of conscience and religion need to be analyzed together with the Law on the relations between the Republic of Poland and the Roman Catholic Church that was passed on the same day. It is only then that the following regulations should be considered: the concordat between the Holy See and the Republic of Poland signed in Warsaw on July 28, 1993, the Law of June 14, 1991 on financing the Catholic University in Lublin from the state budget, and the Law of June 26, 1997 on financing the Papal Theological Academy in

133 Zob. § 1 ust. 1 rozporządzenia Ministrów Pracy i Polityki Socjalnej oraz Edukacji Narodowej z dnia 11 marca 1999 r., w sprawie zwolnień od pracy lub nauki osób należących do kościołów i innych związków wyznaniowych w celu obchodzenia świąt religijnych nie będących dniami ustawowo wolnymi od pracy (Dz. U. 1999, $\mathrm{Nr} 6$, poz. 235). 
Krakow from the state budget. The latter institution presently operates under the name of the Pontifical University of John Paul II. Finally, an analysis is required of a group of three laws of April 5, 2006 on financing the Papal Theological Faculty in Warsaw, Papal Theological Faculty in Wrocław and Jesuit University of Philosophy and Education "Ignatianum" in Cracow respectively. 
